\title{
KEBIJAKAN NASIONAL ANTI-TRAFFICKING DALAM MIGRASI INTERNASIONAL
}

\author{
National Anti-Trafficking Policies in International Migration
}

\author{
Rahmah Daniah dan Fajar Apriani
}

\author{
FISIP Universitas Mulawarman Kalimantan Timur \\ Alamat email: yaniefajar@yahoo.com
}

Naskah Diterima: 28 Agustus 2017

Naskah Direvisi: 24 Oktober 2017

Naskah Diterima: 22 November 2017

\begin{abstract}
This study analyzes national anti-Trafficking policies in international migration especially in guarding Indonesian women workers who are often victims, through a comprehensive analysis of external factors of international and regional commitments on the handling of Trafficking, as well as internal factors of national commitments contained in the PTPPO Law, which is associated with the conception of public policy implementation and the factors that influence it. Through this type of explanative research, this paper explains the causal relationship between phenomena that occur in the input, conversion and output of the anti Trafficking policy in Indonesia qualitatively. Using primary data from the substance of the PTPPO Law and secondary data from various books, journals and reports, this paper elaborates on four issues. Firstly, the government's efforts to change the mindset of women laborers as housemaids, servants and entertainers for lack of expertise; secondly, the weakness of international organizational commitment due to unclear rewards and sanctions for member countries and the closing of information member states on sovereignty issues; thirdly, weakness of regional organizational commitment through ASEAN Declaration due to low awareness of the state in view of the importance of co-management of border lines of member countries and the weak consolidation of the bordering state from institutions and communities in its border areas; fourth, the application of anti-Trafficking policy which is contained in the PTPPO Law is still faced with a number of obstacles from the aspect of resources, communication, disposition and environment in which the policy is implemented. The results of this study indicate that the success of the government's role in eradicating human Trafficking depends on the ability of the people, because human Trafficking is fundamentally influenced by the gender bias pattern that can not be separated from other dimensions related to age, economic, social, cultural and political disability that related to the process of industrialization and globalization. On the other hand, the role of government through law enforcement officers and related public officials requires better coordination, firmer and cleaner in the prevention and protection of Trafficking victims.
\end{abstract}

Keywords: human trafficking, international migration, women labour force, PTPPO Law

Abstrak
Penelitian ini menganalisa kebijakan nasional anti perdagangan manusia dalam migrasi internasional
khususnya dalam mengawal tenaga kerja perempuan Indonesia yang sering menjadi korban, melalui analisis
komprehensif terhadap faktor eksternal dari komitmen internasional dan regional tentang penanganan
perdagangan manusia, serta faktor internal dari komitmen nasional yang tertuang dalam UU PTPPO,
yang dikaitkan dengan konsepsi implementasi kebijakan publik beserta berbagai faktor-faktor yang
mempengaruhinya. Melalui jenis penelitian eksplanatif, tulisan ini menerangkan hubungan-hubungan
kausal antar fenomena yang terjadi pada input, konversi dan output dari kebijakan anti perdagangan
manusia di Indonesia secara kualitatif. Dengan mempergunakan data primer dari substansi UU PTPPO dan
data sekunder dari berbagai buku, jurnal dan laporan, tulisan ini mengelaborasi empat hal. Pertama, upaya
pemerintah dalam mengubah pola pikir keberadaan tenaga kerja perempuan sebagai pembantu rumah
tangga, pelayan dan penghibur karena tidak memiliki keahlian; Kedua, lemahnya komitmen organisasi
internasional dikarenakan belum jelasnya penghargaan dan sanksi bagi negara anggota serta tertutupnya
informasi negara anggota terkait masalah kedaulatan; Ketiga, lemahnya komitmen organisasi regional


melalui Deklarasi ASEAN yang dikarenakan rendahnya kesadaran negara dalam memandang pentingnya pengelolaan bersama jalur perbatasan negara anggota serta lemahnya konsolidasi negara yang berbatasan dari institusi maupun masyarakat di wilayah perbatasannya; keempat, penerapan kebijakan anti perdagangan manusia yang tertuang pada UU PTPPO masih berhadapan dengan sejumlah hambatan dari aspek sumberdaya, komunikasi, disposisi dan lingkungan dimana kebijakan tersebut diimplementasikan. Hasil penelitian ini menunjukkan bahwa bagaimanapun keberhasilan peran pemerintah dalam melakukan pemberantasan perdagangan manusia tergantung dari kemampuan masyarakatnya, sebab perdagangan manusia pada dasarnya dipengaruhi oleh adanya pola bias gender yang tidak lepas dari dimensi lain yang terkait dengan usia, ketidakberdayaan ekonomi, sosial, budaya dan politik yang berkaitan dengan proses industrialisasi serta globalisasi. Pada sisi lain, peran pemerintah melalui aparat penegak hukum dan berbagai pejabat publik yang terkait, membutuhkan koordinasi yang lebih baik, tegas dan bersih dalam penindakan, pencegahan dan perlindungan korban perdagangan manusia.

Kata kunci: migrasi internasional, perdagangan manusia, tenaga kerja perempuan, UU PTPPO

\section{LATAR BELAKANG}

Faktor kependudukan bersifat kritikal bagi hubungan internasional dikarenakan memiliki konsekuensi negatif bagi kehidupan sebuah negara. Semakin meningkatnya interaksi antar masyarakat, maka perpindahan penduduk (migrasi) antar negara semakin mudah seiring dengan pertumbuhan migrasi internasional yang disebabkan oleh peningkatan jumlah penduduk, seperti adanya pergeseran atau perbedaan populasi penduduk antara negara maju dan berkembang, mayoritas negara yang memiliki penduduk besar dimiliki negara berkembang, kemudian adanya revolusi industri (tuntutan ekonomi) yang menyebabkan konsentrasi penyebaran urbanisasi lebih mengarah pada kawasan dengan kondisi ekonomi yang menjanjikan lapangan pekerjaan, serta adanya dukungan informasi dan teknologi yang semakin murah, mudah dan cepat sehingga mengakibatkan arus perpindahan migrasi tersebut semakin meningkat.

Akibat dari adanya migrasi internasional, maka konsekuensi lain yang muncul adalah perdagangan manusia (human trafficking) sebagai isu yang sangat krusial dalam dunia politik tahun 1990-an. Pihak-pihak yang sangat peduli dengan isu perdagangan manusia, khususnya kalangan feminis dan organisasi Hak Asasi Manusia (HAM) mengungkapkan bahwa perdagangan manusia, khususnya sex trafficking meningkat sebagai salah satu masalah migrasi internasional, yang merupakan bentuk perbudakan modern (modern day slavery) yang sangat memerlukan perhatian dan tindakan internasional ${ }^{1}$. Tingginya keberadaan undocumented worker juga menjadi pemicu dalam isu dan kasus yang baru dalam migrasi internasional, sehingga munculnya masalah perdagangan manusiasemakin marak, mendunia dan terus mengalami peningkatan jumlah kasus per tahunnya. Hal inilah yang menjadikan arus perdagangan manusia ada pada setiap negara, tetapi khususnya bagi negara berkembang.

Perdagangan manusia (human trafficking) adalah kejahatan transnasional yang dapat terjadi di dalam maupun lintas batas negara. Munculnya perdagangan manusia seringkali terjadi pada kondisi seseorang yang rentan, diantaranya yang seringkali menjadi korban adalah perempuan dan anak-anak yang dikategorikan pada kondisi yang lemah. Banyaknya kasus eksploitasi terhadap perempuan dan anak dikarenakan pada alasan posisi para perempuan di keluarga sebagai bukan kepala rumah tangga (dianggap sebagai pengurus rumah), sulitnya mencari pekerjaan dan masalah kemiskinan atau ekonomi dijadikan alasan paling utama sehingga perdagangan manusia masih terus meningkat, rendahnya tingkat pengetahuan, seringkali alasan kebutuhan ekonomi yang cukup sulit

Barbara Sullivan, "Trafficking in Human Being”, Gender Matters in Global Politics: A Feminist Introduction in International Relations, 2010: 89-90. 
dibedakan dengan pola hidup konsumtif dan materialisme, tidak memiliki pemahaman mengenai pendidikan yang baik, serta tidak memiliki keterampilan yang memadai menjadi penyebab perdagangan manusia yang cukup signifikan.

Konteks perdagangan manusia di Indonesia terjadi pada tiga hal, yaitu sebagai daerah asal, daerah transit dan daerah tujuan. Sebagai daerah tujuan, perdagangan manusia di Indonesia dikarenakan adanya masalah ekonomi, rendahnya pengetahuan dan lainnya. Sebagai daerah transit, Indonesia dipilih dikarenakan kurangnya pengawasan terutama pada jalur perbatasan, sehingga arus keluar dan masuk manusia terjadi cukup tinggi. Kemudian, Indonesia menjadi daerah tujuan bagi perempuan yang didatangkan dari berbagai daerah untuk tujuan eksploitasi seksual, selain juga dikarenakan proses hukum perdagangan manusia di Indonesia yang dinilai cukup lemah.

Perdagangan perempuan yang terjadi di Indonesia, selain dari adanya faktor dari perempuannya, juga adanya praktek para calo dengan cara menawarkan pekerjaan yang disertai oleh tingginya gaji yang diperoleh. Para calo atau penyalur tersebut juga bekerjasama dengan oknum aparat pemerintah (Pengerah Jasa Tenaga Kerja Indonesia) yang terlibat dalam praktek penipuan, biasanya para calo atau oknum aparat tersebut dikenal sebagai masyarakat di sekitar kawasan tersebut, sehingga tidak menimbulkan kecurigaan terhadap perdagangan manusia yang terjadi.

Kondisidan situasi korban dapat merangsang orang atau kelompok lain melakukan kejahatan terhadapnya, ada kejahatan yang disadari tertapi ada pula kejahatan yang tidak disadari korban yang akan menimpa dirinya, sama halnya dengan korban tindak pidana perdagangan orang, korban menyadari bahwa dapat terjadi tindak pidana perdagangan orang terhadap dirinya dan ada yang tidak menyadari karena ditipu atau dibujuk sehingga menjadi korban tindak pidana perdagangan orang. ${ }^{2}$

Farhana, Aspek Hukum Perdagangan Orang di Indonesia (Jakarta: Sinar Grafika, 2010).
Hal tersebut seringkali mengakibatkan para TKI yang bekerja di luar negeri sering dijadikan sasaran perdagangan manusia dikarenakan perempuan merupakan korban yang paling rentan terhadapkejahatan perdagangan manusia dengan persentasi 90,3\%, sehingga diperlukan perlindungan yang tinggi terhadap para tenaga kerja demi terjaminnya keselamatan kerja para tenaga kerja wanita Indonesia. Komnas Perempuan Jakarta melaporkan bahwa pada tahun 1994-1997 perekonomian ekspor tenaga kerja Indonesia hampir seluruhnya tergantung pada penyebaran pekerja rumah tangga di luar negeri yang mayoritas adalah tenaga kerja perempuan. Di Arab Saudi, pada rentang tahun 1997 angka Tenaga Kerja Indonesia (TKI) lebih banyak perempuan dan hampir seluruhnya di sektor Pekerja Rumah Tangga (PRT), terutama di Timur Tengah (sebanyak 81,13\% di Timur Tengah dan 53,49\% di Asia). Pada tahun 1999. 2000 angka dari Departemen Tenaga Kerja menunjukkan bahwa 70\% dari seluruh buruh migran Indonesia adalah perempuan (untuk Arab Saudi mencapai 90\%) 3 .

Komnas Perempuan Jakarta menyatakan bahwa feminisasi migrasi di Indonesia sebenarnya terjadi sejak tahun 1996, tepatnya pada saat Orde Baru mengintegrasikan dirinya pada perekonomian dunia (globalisasi), tingkat pengangguran yang tinggi dan keresahan tenaga kerja mulai meningkat menyusul dengan jatuhnya harga minyak dan pemerintah membangun basis perekonomiannya beralaskan tenaga kerja murah ke luar negeri (ekspor tenaga kerja). Feminisasi migrasi tersebut termasuk diantaranya perempuan yang masih di bawah umur (anak-anak yang berusia di bawah 18 tahun yang dipalsukan identitasnya menjadi usia dewasa).

Salah satu data yang mendukung adanya feminisasi migrasi tersebut yaitu International Organization for Migration (IOM) sejak tahun 2005 telah mengidentifikasi dan membantu korban perdagangan manusia di Indonesia

Mariana Amiruddin, "Wilayah Tertinggal, Migrasi dan Perdagangan Manusia”, Jurnal Perempuan, No.59 (2008): 8. 
sebanyak 3.339 orang, dimana hampir 90\% dari korban tersebut adalah perempuan, dan lebih dari 25\% nya adalah anak-anak ${ }^{4}$. Feminisasi buruh migran di Indonesia pun sekaligus merepresentasikan adanya feminisasi kemiskinan, yang ditunjukkan dengan semakin banyak perempuan yang dipaksa untuk mencari pekerjaan di luar negeri, dan hingga saat ini lebih dari 70\% buruh migran Indonesia adalah perempuan ${ }^{5}$. Padahal sebelum terjadinya krisis moneter di Indonesia, perempuan Indonesia cenderung lebih banyak bekerja sebagai ibu rumah tangga. Terjadinya pergeseran dan tuntutan peran wanita dalam ekonomi inilah yang menjadi ketertarikan untuk menganalisa keberadaan kebijakan nasional anti-Trafficking dalam migrasi internasional, khususnya dalam mengawal para pekerja migran perempuan Indonesia.

\section{PERMASALAHAN DAN TUJUAN PENELITIAN}

Upaya pencegahan dan pemberantasan perdagangan manusia telah memiliki kerangka hukum dalam lingkup internasional maupun regional. Diawali dengan kemunculan Protokol Palermo yang dilahirkan oleh Perserikatan Bangsa-bangsa, hingga Deklarasi ASEAN sebagai perjanjian regional yang mengatur mengenai perdagangan manusia. Disamping telah membangun komitmen pada lingkup internasional maupun regional, secara nasional pemerintah Indonesia telah pula memberlakukan kebijakan mengenai perdagangan manusia hingga ke daerah. Namun, dari tahun ke tahun kasus perdagangan manusia terutama perempuan dan anak masih mengalami peningkatan.

Maslihati Nur Hidayati. "Upaya Pemberantasan dan Pencegahan Perdagangan Orang Melalui Hukum Internasional dan Hukum Positif Indonesia". Jurnal ALAZHAR Indonesia Seri Pranata Sosial, Volume 1. Nomor 3 (2012), diakses pada 15 Agustus 2017, Pukul 21:30 WITA, http://jurnal.uai.ac.id/index.php/SPS/article/ download/59/46.

Amiruddin, "Wilayah Tertinggal, Migrasi dan Perdagangan Manusia" 8
Melalui penelitian ini, implementasi kebijakan anti perdagangan manusia di Indonesia dikaji secara komprehensif mengenai faktor internal maupun eksternal dari komitmen penanganan perdagangan manusia, yang kemudian dikaitkan dengan konsepsi keberhasilan implementasi suatu kebijakan publik beserta berbagai faktorfaktor yang mempengaruhinya. Sehingga penelitian ini bertujuan untuk menerangkan hubungan-hubungan kausal yang terjadi pada input, konversi, output dan implementasi dari kebijakan nasional anti perdagangan manusia yang diimplementasikan di Indonesia serta mengidentifikasi berbagai hambatan serta tantangan yang perlu diatasi oleh pemerintah Indonesia.

\section{PENDEKATAN TEORITIS DAN KERANGKA PEMIKIRAN}

\section{Berbagai Pandangan tentang Trafficking}

Berdasarkan penelitian Robinson mengenai kegiatan advokasi di kalangan LSM mengenai trafficking yang berkembang di negara-negara maju, khususnya di Amerika Serikat, terdapat tiga pandangan atau pemikiran ${ }^{6}$ :

1) Pemikirankelompokabolisionis (abolitionists groups)

Pemikiran ini dimotorioleh Coalition Againts Trafficking in Women (CATW). Intisari pemikiran kelompok ini menempatkan prostitusi, trafficking dan kekerasan terhadap perempuan di dalam posisi yang sama. Ketiga elemen tersebut diyakini tidak dapat dipisahkan dari pengamatan, analisa dan solusi pemecahannya. Kelompok ini sepakat bahwa industri seks harus dihilangkan dari muka bumi karena objektifikasi dan perlakuan opresif mereka terhadap perempuan, melekat pada aktivitas seks yang hanya untuk diperdagangkan. Kelompok ini dalam berbagai kegiatan dan kampanyenya sering

Fiona Robinson, "Sec Trafficking and the Political Economy of Care: A Feminist Moral Analysis", Lokakarya the Political Economy of Care: Transnational Perspectives, 4-6 Juni 2008. 
seiring dengan kelompok agama atau konservatif sebagaimana sangat terlihat di Amerika Serikat pada masa pemerintahan George Bush tahun 2001.

2) Pemikiran kelompok non abolisionis. Pemikiran ini dimotori oleh Global Alliance Against Trafficking (GAATW), memiliki pandangan dan posisi yang berbeda dengan pemikiran kelompok abolisionis. Pemikiran ini memberikan pemahaman yang lebih luas dari kata trafficking dengan memasukkan bentuk lain dari buruh paksa (forced labor) bersama-sama dengan prostitusi yang dieksploitasi (coerced prostitution). Kelompok ini menentang berbagai bentuk tekanan atau kekerasan dari pekerja seks komersial di bawah rubrik prostitusi yang dieksploitasi. Meskipun demikian, pada saat bersamaan mereka memberikan dukungan penuh bahwa pekerjaan seks komersial sebagai sebuah profesi pekerjaan. Dalam perkembangannya, karena begitu fokus pada masalah perdagangan manusia, kelompok ini seringkali mengabaikan fenomena sosial yang berkaitan, misalnya pengalaman manusia dalam berimigrasi dan bekerja. Pandangan anti trafficking kemudian berubah menjadi "sesuatu" yang terlepas dari konteksnya, dan menjadi sebuah kajian tersendiri. Akibat lanjutannya, hal tersebut banyak dikritik karena kelompok ini menangani masalah trafficking tanpa memahami konteks buruh dan migrasi yang berubah dalam dunia yang mengglobal secara cepat. Mereka terjebak dalam pandangan yang melihat trafficking semata-mata hanya sebagai sebuah kejahatan dan bukan sebagai hasil dari sejumlah faktor sosial yang saling berkaitan.

3) Pemikiran kalangan pekerja seks komersial (sex workers).

Kelompok ini berasal dari kalangan pekerja seks komersial itu sendiri (sex workers), khususnya yang tergabung dalam organisasi seperti Network of Sex Work Projects (NSWP) yang merupakan koalisi dari 40 kelompok internasional, Sex Workers Outreach Project dan Sex Workers Project in New York. Kelompok ini mengkritisi penggunaan istilah trafficking dalam menggambarkan kondisi kelompok migran pekerja seks komersial. Dalam banyak kasus, kelompok ini relatif siap untuk menggugat Komisi Kejahatan PBB (United Nations Crimes Commission), misalnya dalam perangkat hukum internasional mengenai trafficking. Secara historis, menurut kelompok ini perangkat dan aturan-aturan hukum yang ada lebih difokuskan pada upaya-upaya untuk melindungi "perempuan baik-baik" (innocent women) untuk tidak terjebak dalam prostitusi daripada memastikan dan melindungi Hak Asasi Manusia dari perempuan-perempuan yang berada dalam industri seks. Dalam aktivitasnya, dengan bendera menentang kampanye anti prostitusi, kelompok ini sering sejalan dengan organisasi feminis yang masuk dalam pandangan kedua seperti GAATW. Kelompok ini mengadakan riset mengenai trafficking dan memberikan bantuan dan penyuluhan sosial terhadap individuindividu yang terlibat dalam industri seks, tetapi mereka tidak menentang pekerja seks komersial itu sendiri. Perhatian mereka tertuju pada memberdayakan pekerja seks komersial dan membantu mengurangi akibat-akibat buruk yang dialami pekerja seks komersial dengan cara diantaranya memberikan konseling, melakukan pemeriksaan kesehatan secara rutin, dan layanan pendukung sosial lainnya. Dalam kontestasi politik yang ada, karena sikap dan pandangan mereka yang menentang kelompok abolisionis, mereka mengalami marjinalisasi secara sosial dan politik dan mendapatkan label sebagai "pro-prostitution lobby"7.

Faktor-faktor di balik perdagangan orang, khususnya perempuan dan anak, ternyata tidak dapat dipisahkan dari masalah-masalah

Ronald Weitzer, "The Social Construction of Sex Trafficking: Ideology and Institutionalization of a Moral Crusade", Politics and Society No.35 (2007): 447. 
ketertinggalan atau kemiskinan. Dalam buku IV tentang Perdagangan Perempuan dan Anak Perempuan yang diterbitkan oleh International Labour Organization (ILO) Tahun 2004, ditemukan bahwa proses feminisasi kemiskinan, pengangguran yang kronis dan kurangnya kesempatan ekonomi adalah beberapa faktor yang mempengaruhi perdagangan perempuan dan anak. Kaum miskin adalah alasan pertama bagaimana resiko dan kerentanan terhadap perdagangan manusia terjadi ${ }^{8}$.

Sedangkan United Nations Global Initiative to Fight Human Trafficking mengungkapkan sebab-sebab umum terjadinya trafficking yaitu:

a) Kekerasan berbasis gender,

b) Praktek-praktek ketenagakerjaan yang diskriminatif,

c) Struktur sosial yang patriarkal,

d) Memudarnya jaringan ikatan keluarga,

e) Marjinalisasi etnik, ras dan agama,

f) Pemerintahan yang korup dan gagal,

g) Persoalan status (sebagai warga negara atau penetap legal yang berkaitan dengan kerja),

h) Peran dan posisi perempuan dalam keluarga,

i) Hirarki kekuasaan dan tertib sosial,

j) Tanggungjawab dan peran anak-anak,

k) Menikah dini,

1) Tingginya laju perceraian dan stigma sosial yang menyertainya,

m) Rusaknya perkembangan kepribadian,

n) Terbatasnya prestasi atau pencapaian pendidikan, dan

o) Terbatasnya kesempatan ekonomi .

Mencermati sejumlah penyebab umum terjadinya trafficking berdasarkan daftar tersebut di atas, dapat disadari bahwa masalah trafficking adalah masalah yang rumit. Atas dasar itu pula berbagai kebijakan pemerintah maupun organisasi internasional yang diarahkan untuk menangani masalah trafficking dalam kenyataannya tidak selalu tepat sasaran atau berhasil.

\footnotetext{
8 Amiruddin, "Wilayah Tertinggal, Migrasi dan Perdagangan Manusia" 11.

Sullivan, "Trafficking in Human Being", 94-95.
}

Pettman mengatakan bahwa secara lebih persisnya, dapat dikatakan negara-negara "asal" (sending area) dari korban trafficking berada di wilayah Eropa Timur, Afrika Barat, Asia Tenggara dan Asia Selatan. Sementara itu, negara "tujuan" (destination area) dari trafficking adalah wilayah Eropa Barat, Amerika Serikat, Jepang, Timur Tengah (Israel, Arab Saudi dan Emirat Arab) ${ }^{10}$. Namun berdasarkan laporan United Nations Development Index, ternyata negara-negara "asal" korban trafficking justru berasal dari negara-negara tingkat menengah, dan bukan mayoritas orang-orang miskin di dunia yang menjadi target utama dari korban trafficking seperti dugaan semula ${ }^{11}$. Walaupun perandariketimpanganglobal (globalinequalities) dan proses globalisasi memiliki peran yang besar juga dari muncul dan berkembangnya trafficking atau perdagangan manusia dalam 17 tahun belakangan ini.

Apapun perdebatan yang muncul mengenai trafficking, tidak bisa dipungkiri bahwa dimensi gender merupakan faktor yang menentukan, bahkan sebagai faktor yang terpenting. ${ }^{12}$ Kempadoo menyatakan bahwa perempuan terepresentasikan secara tidak proporsional diantara kalangan miskin, tidak terdokumentasikan, terlilit utang, dan menjadi tenaga kerja migran internasional. Sementara itu, dunia diwarnai dengan diskriminasi dan misogini yang sangat memiliki dampak pada kehidupan perempuan, dan membatasi kesempatan ekonomi mereka. Ini artinya, perempuan suka tidak suka harus selalu berhubungan dengan tata dunia yang berbasis rasial dan bias gender dalam berimigrasi untuk mencari pekerjaan dengan upah yang lebih baik $^{13}$.

10 Jindy Pettman, "Migration", Gender Matters in Global Politics: A Feminist Introduction in International Relations (2010): 254.

11 Nur Iman Subono, "Trafficking in Human Beings dalam Angka dan Perdebatan”, Jurnal Perempuan, No.68 (2010): 32.

12 Subono, "Trafficking in Human Beings dalam Angka dan Perdebatan", 32.

13 Kamala Kempadoo, "The War on Human Trafficking in the Caribbean", Race and Class, No.49 (2) (2007): 83. 
Hampir seluruh jalur migrasi legal yang ada sangat kuat sekali bias untuk kerja-kerja yang secara tradisional dilakukan oleh lakilaki. Hanya ada dua tempat kerja bagi kalangan perempuan, yakni dunia pembantu rumah tangga dan hiburan, yang mana pada dua area kerja tersebut umumnya sangat sedikit mendapat perlindungan dari Undang-undang tenaga kerja yang berlaku. Atas dasar hal itu maka Subono menyatakan bahwa perjalanan migrasi untuk mencari hidup yang lebih baik bagi perempuan memang sangat rentan untuk terjebak dalam perdagangan manusia atau trafficking ${ }^{14}$. Trafficking dikatakan sebagai tragedi kemanusiaan yang sudah dianggap sebagai masalah kejahatan yang terorganisir, yang dalam perkembangannya kemudian dikaitkan dengan faktor keamanan negara (state security). Sehingga agenda penanganan trafficking sangat ditujukan pada upaya kontrol ketat imigrasi, keamanan dan proteksi perbatasan dan pengawasan komprehensif yang melampaui isuisu Hak Asasi Manusia, khususnya hak asasi perempuan.

\section{Pandangan Teori Sistem}

Secara sederhana dalam menganalisa bagaimana sebuah Undang-undang atau peraturan bagi sebuah negara dapat muncul, maka kerangka sistem digunakan dalam melihat proses tersebut, seperti adanya keberadaan tuntutan dan dukungan pada faktor internal dan eksternal suatu negara (input) yang kemudian dikonversi (proses) berbagai masukan dari faktor-faktor tersebut yang menghasilkan sebuah output bagi sebuah negara. Sistem inilah yang digunakan dalam menganalisa proses munculnya Undang-undang atau peraturan bagi suatu negara.

14 Subono, "Trafficking in Human Beings dalam Angka dan Perdebatan”, 32.
Skema Sistem Politik David Easton

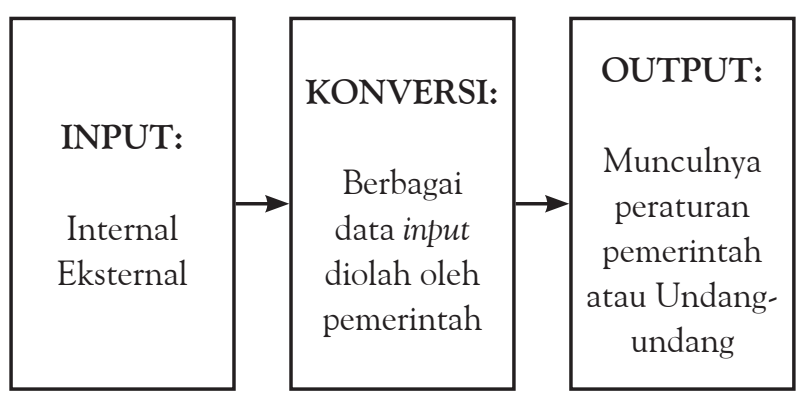

Sumber: Ronald H. Chilcote dalam Mohtar Mas'oed, $1984^{15}$

Fungsi input pada sistem politik adalah berbagai tuntutan dan dukungan masyarakat sebagai masukan internal, biasanya terdiri atas kelompok-kelompok sosial atau masyarakat secara umum, kelompok-kelompok tersebut bisa dalam bentuk dukungan atau tuntutan terhadap kondisi sosial yang sedang terjadi, tuntutan dan dukungan yang dilakukan oleh internal setting bisa dalam bentuk positif dan negatif disesuaikan dengan tingkat kebutuhan suatu negara, sedangkan untuk masukan eksternal yaitu kemampuan beradaptasi terhadap 'trend internasional' yang sedang terjadi, perubahan lingkungan eksternal harus diikuti oleh suatu negara, apabila negara tersebut tidak ingin dikucilkan dalam pergaulan internasional. Adaptasi negara melalui lingkungan internasional terlihat dari berbagai kerjasama dalam organisasi regional dan global.

Fungsi konversi pada sistem politik yaitu dalam mengolah suatu kebijakan maka berbagai faktor yang mempengaruhi kebijakan yang dikeluarkan oleh pemerintah atau lembagalembaga pemerintahan (eksekutif, yudikatif dan legislatif) sebagai pertimbangan dan masukan, karena dalam keberadaan lembagalembaga tersebut kadang tidak mencapai suatu kesepakatan dalam perumusan suatu Undangundang, maka tawar menawar antar aktor pemerintah juga terjadi disini, berbagai tawaran keuntungan dan kerugian politik dalam pemerintahan menjadi masukan penting disini, walaupun dalam membuat keputusan suatu negara tidak akan mampu mengakomodir segala tuntutan dari berbagai kalangan masyarakat.

15 Mohtar Mas'oed dan Colin MacAndrews, Perbandingan Sistem Politik, (Yogyakarta: Gadjah Mada University Press, 1984). 
Fungsi output pada sistem politik yaitu implementasi kebijakan nasional anti trafficking sebagai hasil dari berbagai olahan dari konversi, di Indonesia ini, maka kerangka pemikiran biasanya output diterapkan terlebih dahulu penelitian ini adalah sebagai berikut:

Kerangka Pemikiran Kebijakan Nasional Anti Trafficking dalam Migrasi Internasional

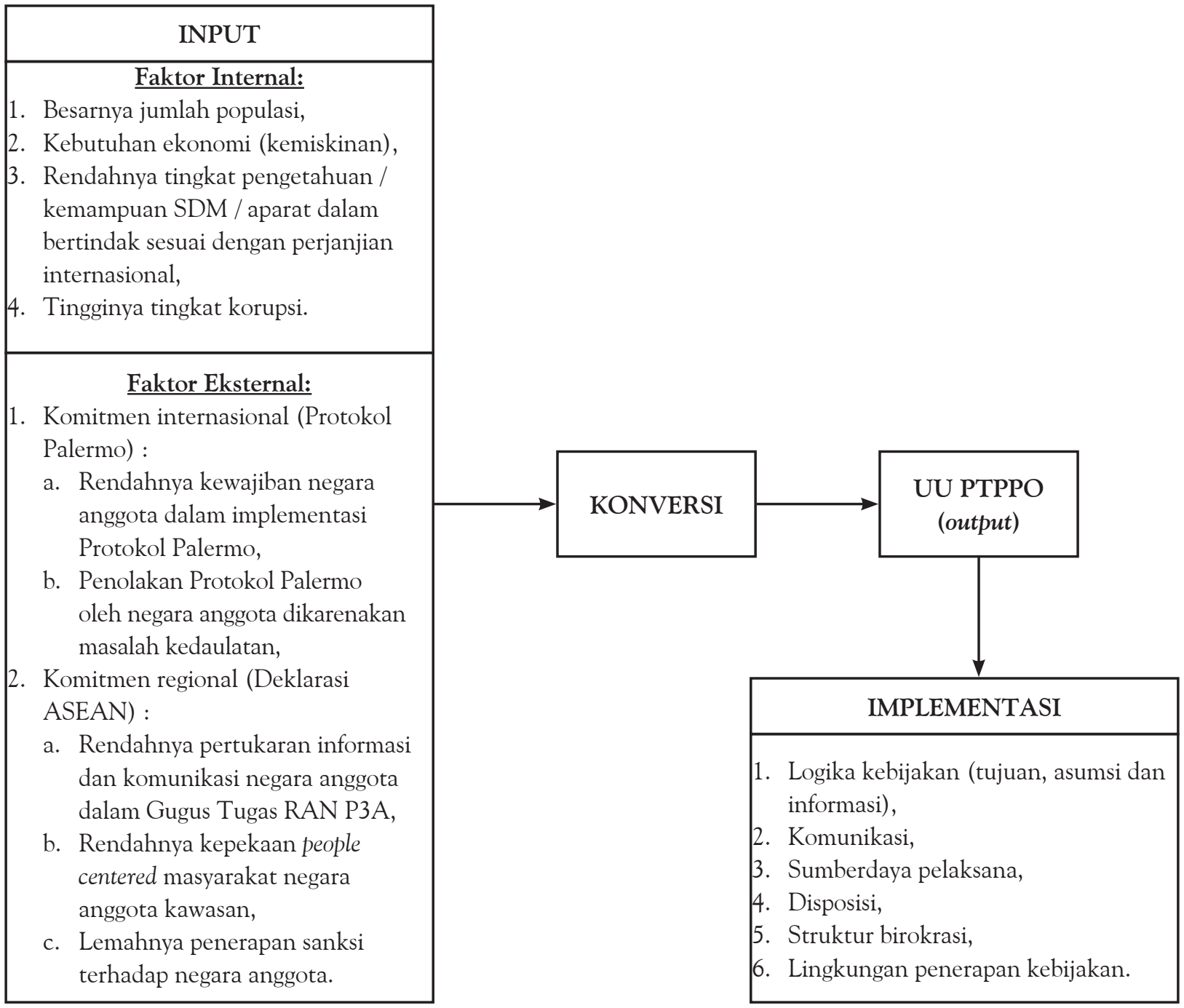

Sumber: Peneliti, 2017.

sebagai bahan percobaan (uji coba), apabila muncul penolakan yang besar maka feedback terjadi untuk masuk kembali ke input dan kemudian dikonversi kembali. Munculnya output biasanya hasil dari masukan input yang lebih besar dukungan terutama pada kelompok mayoritas. Hal inilah seringkali menjadi kekurangan sistem politik yang sering mengambil keputusan mada suara mayoritas, tentunya untuk kelompok minoritas akan sulit terakomodir dalam sistem politik tersebut.

Berdasarkan landasan teoritis tentang trafficking dan konsep sistem politik yang menjadi pendekatan untuk mengkaji masalah

\section{METODE PENELITIAN}

Metode penelitian adalah suatu prosedur atau cara untuk mengetahui sesuatu yang mempunyai langkah-langkah sistematis. Adapun metode yang akan digunakan oleh penulis dalam tulisan ini terdiri atas beberapa metode $^{16}$.

Jenis penelitian yang digunakan dalam tulisan iniadalah eksplanatif, yaitu menerangkan hubungan-hubungan kausal antar fenomena yang terjadi pada input, konversi dan output kebijakan nasional anti trafficking dalam migrasi

16 David Silverman, Doing Qualitative Research (London: Sage, 2005). 
internasional. Penelitian ini juga menguraikan adanya keterhubungan faktor-faktor pemicu secara sistemik, terutama dalam implementasi UU PTPPO di Indonesia.

Jenis data yang digunakan adalah data primer antara lain substansi UU PTPPO dan data sekunder yang telah diolah oleh pihak lain seperti buku, jurnal dll. Data sekunder yang digunakan melalui berbagai kajian literatur atau kajian kepustakaan yang meliputi sumber bahan bacaan akademik baik cetak maupun elektronik. Metode pengumpulan data yang dilakukan untuk mendapatkan informasi yang dibutuhkan sesuai dengan masalah yang diselidiki melalui telaah pustaka dari berbagai literatur. Teknik analisis data yang digunakan adalah kualitatif, yaitu menggambarkan dan menganalisa persoalan kebijakan nasional anti trafficking dalam migrasi internasional terutama pada implementasi UU PTPPO di Indonesia.

\section{PEMBAHASAN}

Input Komitmen HAM Internasional dalam Penanganan Trafficking

Dalam upaya mencegah dan memberantas trafficking, dikenal sebuah kerangka hukum internasional yang menetapkan standar penanganan dan pemenuhan hak korban trafficking yaitu United Nations Trafficking Protocol atau dikenal juga sebagai Protokol Palermo $^{17}$. Sejarah kelahiran protokol tersebut terkait Resolusi Majelis Umum Perserikatan Bangsa-bangsa 53/111 pada 9 Desember 1998, yang pada saat itu majelis memutuskan untuk membentuk sebuah komite ad hoc antar pemerintah tanpa batasan dengan tujuan mengelaborasi sebuah konvensi internasional yang komprehensif untuk menentang kejahatan transnasional yang terorganisir dan untuk membahas elaborasi dari salah satunya, sebuah instrumen internasional yang menangani perdagangan terhadap perempuan dan anak.

\footnotetext{
United Nations Protocol to Prevent, Suppress and Punish Trafficking in Persons Especially Women and Children Suplementing the United Nations Convention Against Transnational Organised Crime (2000).
}

Bertempat di Italia, Perserikatan Bangsabangsa pada akhirnya merumuskan sebuah protokol untuk mencegah, menindak dan menghukum perdagangan manusia, terutama perempuan dan anak (United Nations Protocol to Prevent, Suppress and Punish Trafficking in Persons, Especially Woman and Children ${ }^{18}$. Protokol Palermo berlaku sejak 25 Desember 2003, yang dirancang untuk memperkokoh dan meningkatkan kerjasama internasional guna mencegah dan memerangi perdagangan manusia. Protokol Palermo juga dipromosikan untuk memperbaiki perlindungan dan bantuan bagi para korban. Protokol Palermo mendorong agar setiap negara pihak harus menetapkan langkah-langkah legislatif dan langkah-langkah lain yang dianggap perlu untuk mencegah, menindak dan menghukum perdagangan orang, terutama perempuan dan anak-anak ${ }^{19}$.

Definisi trafficking dalam UN Protocol adalah perekrutan, pengangkutan, pemindahan, penampungan atau penerimaan orang, dengan ancaman atau penggunaan kekerasan atau bentuk lain dari paksaan, penculikan, penipuan, penyesatan, penyalahgunaan kekuasaan atau posisi rentan, pemberian atau penerimaan pembayaran atau keuntungan untuk mencapai persetujuan dari seseorang yang memiliki kekuasaan atas orangain, untuk tujuan eksploitasi. Eksploitasi meliputi sekurang-kurangnya eksploitasi dalam pelacuran seseorang atau bentuk eksploitasi seksual lainnya, kerja atau pelayanan paksa, perbudakan atau praktek-praktek serupa perbudakan, penghambaan atau pengambilan organ-organ.

Dalam United Nation Office on Drugs and Crime Global Report on Trafficking in Persons ditemukan bahwa sebelum tahun 2003 hanya 35\% negara dari 155 negara dan wilayah yang

\footnotetext{
Marcella Nirmala Chrisna Moeri, Idin Fasisaka, dan Putu Titah Kawitri Resen. "Implementasi Protokol dalam Menanggulangi Permasalahan Tenaga Kerja Wanita Indonesia yang Menjadi Korban Human Trafficking". Jurnal Hubungan Internasional, Volume 1 Nomor 1 (2016), diakses pada 15 Agustus 2017, Pukul 21:00 WITA, https:// ojs.unud.ac.id/index.php/hi/article/view/24370/15809.

19 R. Valentina Sagala, "Membaca UU PTPPO dalam Perspektif HAM”, Jurnal Perempuan, No.68 (2010): 87.
} 
tercakup dalam laporan tersebut, mempunyai perundang-undangan mengenai perdagangan manusia. Per bulan November 2008, 80\% negara telah mempunyai perundang-undangan mengenai perdagangan manusia, namun 54\% negara membentuk unit anti perdagangan manusia di kepolisian. ${ }^{20}$

Persoalan perdagangan manusia menyangkut human security pada sebuah negara, tetapi tentunya juga mempengaruhi negara lainnya karena melewati batas negara yang akan mengancam human security di negara lainnya. Karakter persoalan ini menjadi dasar diangkatnya persoalan perdagangan manusia dalam Protokol Palermo, apalagi mengingat bahwa keamanan manusia bersifat universal. Untuk negara-negara maju, persoalan personal security sangat ketat sehingga segala sesuatu yang berhubungan dengan keamanan manusia bersifat sangat mutlak, bahkan pemerintahnya dapat dituntut apabila terjadi pelanggaran HAM pada negaranya. Walaupun untuk kasus di negara berkembang hal tersebut dapat dikatakan masih jarang. Hal tersebut membuat negara-negara maju sangat waspada dan mengawasi negara berkembang, khususnya terkait masalah personal security apabila mereka melakukan kerjasama, misalnya dalam kerjasama ekonomi.

Padahal keberadaan Protokol Palermo dimaksudkan untuk memberikan kesempatan pada beberapa negara dalam perjanjian ini untuk membentuk pengaturan dan kewajiban dari berbagai masalah internasional yang terjadi, diantaranya tentang perdagangan manusia. Protokol Palermo juga memberikan 'prinsipprinsip' yang tegas bagi negara yang memiliki masalah perdagangan manusia, sehingga prinsip tersebut dapat dijadikan dasar kerangka kerjasama mengenai masalah perdagangan manusia yang telah lama terorganisir dan melintasi batas negara dengan negara lainnya, serta sebagai bentuk pengikat dari kerjasama yang terjalin ketika negara-negara tersebut telah meratifikasinya.

$20 \quad$ Emmy Lucy Smith, "Implementasi UU PTPPO bagi Anak Korban Perdagangan”, Jurnal Perempuan, No.68 (2010): 11.
Namun pada saat suatu negara meratifikasi sebuah protokol internasional, tentunya terdapat konsekuensi. Misalnya Indonesia, pasca ratifikasi Protokol Palermo maka kewajiban yang harus dipenuhi adalah membuat peraturan perundangundangan nasional yang terkait dengan protokol internasional yang telah diratifikasi. Berbagai ketentuandan kewajiban yang ada dalam Protokol Palermo harus dimunculkan dalam peraturan tersebut sebagai bagian dari pedoman dan landasan hukum nasional, sehingga perumusan isi Undang-undang nasional mengacu pada isi perjanjian internasional tersebut. Hasil dari perumusan Undang-undang terkait perdagangan manusia tersebut, cenderung "sedikit" memberatkan perilaku nasional, karena negara yang meratifikasi sebuah perjanjian internasional belum tentu memiliki kondisi dalam negeri dan komponennya yang mampu beradaptasi sesuai dengan perjanjian internasional yang diratifikasi.

Keadaan tersebut seringkali menjadikan bertolak belakangnya kesiapan aparat hukum di Indonesia dalam menerapkan aturan dari Protokol Palermo, yang seringkali dikatakan belum mampu akibat beberapa alasan. Diantaranya seringkali cenderung mengabaikan keberadaan Protokol Internasional atau lebih sering menggunakan hukum nasional yang dianggap pedoman paling sempurna dalam implementesinya, selain itu ketidakmampuan dan kebingungan aparat penegak hukum dalam menterjemahkan isi dari setiap pasal yang termuat dalam protokol internasional tersebut.

Disamping itu, sering pula muncul benturan antara hukum internasional dan hukum nasional, yang menjadi kendala signifikan pada implementasinya karena memiliki kondisi sosial dan budaya yang berbeda. Hukum internasional yang lahir dan diterapkan pada negara yang telah memiliki sistem pemerintahan yang kondusif, tentunya berbeda dengan negara berkembang yang masih memiliki permasalahan sistem pemerintahan yang belum baik, sehingga benturan budaya menjadi "kacamata" atau pandangan yang berbeda ketika penerapan hukum tersebut dilakukan pada sebuah negara. 
Kendala lainnya pada masalah adanya kewajiban suatu negara untuk melaporkan penerapan protokol yang seringkali dianggap sebagai "terbukanya" informasi bagi negara tersebut. Keterbukaan informasi tersebut diyakini akan "membuka" informasi lainnya, misalnya informasi tentang ekonomi dan keamanan, sehingga Indonesia seringkali tidak memberikan informasi mengenai perdagangan manusia secara menyeluruh dengan alasan kedaulatan negara akan menjadi lebih "terbuka" dengan melakukan hal tersebut.

Untuk itu, mengenai komitmen HAM Internasional dalam penanganan perdagangan manusia sebenarnya sudah cukup baik dari sisi Protokol internasional yang dapat dijadikan landasan kebijakan bagi sebuah negara anggota. Namun ketika "kewajiban" yang harus dijalankan oleh suatu negara anggota tersebut tidak dijalankan dengan baik, maka keberadaan protokol internasional tidak dapat berfungsi dengan maksimal bagi sebuah negara akibat dari kurangnya kontrol dari badan internasional karena "tertutup"nya informasi dari negara yang meratifikasinya.

\section{Input Komitmen HAM Regional dalam Penanganan Trafficking}

Pada lingkup regional, di wilayah ASEAN belum ada perjanjian regional yang khusus mengatur mengenai trafficking (masih menggunakan perjanjian internasional). Namun pada 29 November 2004, negara anggota ASEAN telah mengeluarkan Deklarasi ASEAN Menentang Perdagangan Orang, khususnya Perempuan dan Anak, yang pada intinya bersama-sama menyatakan bahwa:

1) Membangun jaringan vokal regional untuk mencegah dan memerangi perdagangan orang, terutama perempuan dan anakanak, di kawasan ASEAN,

2) Mengadopsi langkah-langkah untuk melindungi integritas dari paspor masingmasing, dokumen perjalanan dinas, identitas dan dokumen perjalanan lainnya, dari penipuan,
3) Melakukan pertukaran reguler dari informasi yang beredar tentang arus migrasi yang relevan, kecenderungan dan pola, penguatan pengawasan perbatasan dan mekanisme pemantauan, dan berlakunya legislasi yang dibutuhkan dan dapat diberlakukan,

4) Mengintensifkan kerjasama antara imigrasi dan penegak hukum lainnya yang berwenang,

5) Membedakan korban perdagangan orang dari para pelaku, dan mengidentifikasi negara asal dan kebangsaan korban tersebut dan kemudian memastikan bahwa korban tersebut diperlakukan secara manusiawi dan disediakan bantuan medis dan bantuan lainnya yang penting yang dianggap tepat oleh masing-masing negara penerima, termasuk repatriasi cepat ke negara asal masing-masing,

6) Melakukan tindakan untuk menghormati dan melindungi martabat dan Hak Asasi Manusia dari korban perdagangan orang,

7) Melakukan tindakan/langkah koersif terhadap individu dan/atau sindikat yang terlibat dalam perdagangan orang dan harus menawarkan satu sama lain bantuan seluas mungkin untuk menghukum kegiatan tersebut, dan

8) Mengambil langkah-langkah untuk memperkuat kerjasama regional dan internasional untuk mencegah dan memberantas perdagangan orang ${ }^{21}$.

Kendati dalam proses penyatuan global yang lebih kecil dimunculkan kawasan dengan tujuan untuk mempercepat proses tersebut, tetapi dalam menghadapi masalah seperti perdagangan manusia antar negara dengan cakupan wilayah yang lebih sempit seperti Asia Tenggara yang muncul dalam konteks ASEAN, maka upaya dari Deklarasi ASEAN sangat "kecil" terlihat.

Padahal telah ada beberapa komunikasi pada jalur regional yang telah dilakukan oleh

$21 \quad$ Thaufiek Zulbahary, "Menilai Dampak Kebijakan Anti Trafficking di Indonesia terhadap HAM Kelompok Rentan dan Korban”, Jurnal Perempuan, No.68 (2010): 55. 
Indonesia, diantaranya pada Mei 2005 telah disepakati melalui Konferensi Kepolisian ASEAN (ASEANAPOL) upaya mengatasi kejahatan lintas batas negara termasuk perdagangan manusia. Di dalam konferensi tersebut disepakati komunike bersama mengenai kerjasama regional untuk mengatasi pemalsuan dokumen perjalanan (fraudulent travel document), penipuan lintas negara (transnational fraud), dan perdagangan manusia (human Trafficking). Komunikasi tersebut juga diperkuat oleh Pertemuan Tingkat Menteri ASEAN (AMMTC) tentang kejahatan transnasional ke-5 di Hanoi pada November $2005^{22}$. Kemudian pada Januari 2006 bahkan Indonesia juga mengadakan pertemuan dengan Malaysia melalui Presiden dan Perdana Menteri di Bukit Tinggi, Sumatera Barat, yang membahas mengenai praktik-praktik human trafficking. Kedua pihak berkomitmen tinggi untuk mengatasi persoalan tersebut, tetapi ternyata berbagai pertemuan formal yang dilakukan pemerintah tidak memberikan hasil yang signifikan bagi persoalan pemberantasan perdagangan manusia.

Komunikasi yang telah dijalankan secara formal melalui pemerintah tidak mampu meningkatkan keterhubungan dan kedekatan geografis antar negara untuk menjadi alasan bahwa dengan adanya kedekatan wilayah tersebut terbangun "kepekaan" negara dalam menghadapi masalah yang sama, yaitu perdagangan manusia, terutama yang melintasi perbatasan dengan negara di sekitarnya. Padahal Deklarasi ASEAN tersebut harusnya mampu menjadi pedoman kerjasama antar negara yang berbatasan untuk bersama-sama menyelesaikan persoalan perdagangan manusia yang terjadi di perbatasan terluar negara. Kerangka kerjasama tersebut sifatnya pun lebih cepat, mudah dan "murah" untuk secara bersama-sama mengatasi persoalan perbatasan negara-negara yang berbatasan, walaupun hal ini secara formal telah difasilitasi secara formal

22 Moeri, Fasisaka, dan Resen. "Implementasi Protokol dalam Menanggulangi Permasalahan Tenaga Kerja Wanita Indonesia yang Menjadi Korban Human Trafficking”. melalui General Border Committee (GBC) Gugus Tugas RAN P3A (Rencana Aksi Nasional Penghapusan Perdagangan Perempuan dan Anak) yang dibentuk oleh Indonesia-Malaysia dan Indonesia-Filipina. Namun dalam implementasinya, kerjasama tersebut hanya seperti pertemuan rutin saja tanpa ada hasil yang memuaskan.

Tahun 2011 melalui KTT ASEAN ke-18 telah dilakukan kerjasama kawasan dalam upaya peningkatan pemberantasan perdagangan manusia, tetapi terdapat munculnya sikap close regionalism antar negara yang disebabkan oleh rendahnya kesadaran untuk menciptakan saluran-saluran informal dan formal antar negara. Saluran formal yang dimaksud misalnya berupa pertukaran informasi tentang adanya perdagangan manusia yang melintasi batas masing-masing negara yang dilakukan oleh pemerintah. Hal tersebut cukup sulit dilakukan karena masing-masing negara menganggap masalah kedaulatan menjadi terbuka bagi pihak negara tetangga. Sedangkan untuk saluran informal juga tidak adanya kesadaran dari masyarakat di wilayah perbatasan sebagai informan bagi masing-masing negara, kurangnya konsolidasi secara menyeluruh untuk lingkungan internal sehingga menjadi kendala interaksi masing-masing negara, baik konsolidasi instansi antar negara maupun antara masyarakat dengan pemerintahannya, sehingga rendahnya kapasitas salah satu negara yang berbatasan juga dijadikan alasan bagi negara tertentu untuk tidak ingin berbagi informasi mengenai adanya perdagangan manusia lintas batas negara.

Salah satu prinsip untuk langkah-langkah memperkuat kerjasama ini seharusnya adalah people centered sehingga diperlukan "kepekaan" masyarakat yang terlibat secara langsung sebagai bagian dari informan untuk memberantas perdagangan manusia, apalagi seharusnya terdapat tingkat kesadaran yang baik dari masyarakat karena masyarakat itu sendiri yang menjadi korban. Maka peran masyarakat dalam penegakan hukum bagi suatu negara sangat penting karena masyarakat bagian dari 
berjalannya hukum bagi suatu negara. Apabila masyarakat baik dalam menjalankan perannya, maka penegakan hukum juga akan berjalan dengan baik. Demikian pula sebaliknya. Dengan demikian, peran masyarakat disini bukan hanya sebagai informan saja tetapi mereka merupakan bagian dari proses hukum perdagangan manusia, yang tentunya dapat semakin membaik.

Keterikatan antar negara di wilayah kawasan cenderung rendah, seperti tingkat kesadaran bahwa mereka memiliki dimensi atau ruang yang sama pada masalah transnasional. Artinya apabila terjadi peningkatan perdagangan manusia di negara tetangganya, maka terjadi kecenderungan negara tetangga akan menjadi negara transit atau negara yang dituju. Dengan demikian, di dalam kerjasama kawasan apabila salah satu negara aman dari perdagangan manusia, maka negara sekitarnya juga mengalami hal yang sama. Contohnya kasus berbagai bom yang terjadi di Indonesia adalah hasil dari kejahatan lintas batas yang terjadi apabila perbatasan tidak dijaga dengan baik.

Apalagi bila dilihat dari identitas, fisik, bahasa dan budaya yang cenderung memiliki kesamaan pada masyarakat di kawasan tersebut, mengakibatkan bercampurnya manusia yang memiliki kewarganegaraan, baik yang secara legal maupun ilegal, menjadi sukar untuk membedakannya. Inilah yang dimaksudkan bahwa negara harus mampu menterjemahkan kebutuhan-kebutuhan "regionalnya" secara komprehensif, sehingga output regionalism bermanfaat bagi negara-negara yang memiliki kesadaran tinggi akan pentingnya kebutuhan regionalisme.

Deklarasi ASEAN menjadi kurang tajam dalam implementasinya disebabkan oleh aturan institusional yang lemah dalam tataran lapangan. Dalam hal ini artinya "aturan main" yang dilakukan oleh masing-masing negara tidak ketat, misalnya implementasi di lapangan pada masing-masing negara dapat sesuai dengan keinginan masing-masingnegara, yangkemudian memicu komunikasi yang tidak harmonis ketika ketidaksesuaian di lapangan menjadi masalah bagi "institusional" kawasan. Sebagaimana pada Bali Process Regional Ministerial Conference (Bali Process) dalam konferensi Regional Ministerial Conference on People Smuggling Trafficking in Personal and Related Transnational Crime yang diselenggarakan dalam rangka membangun perbatasan negara anggota kawasan, ternyata berakhir hanya dengan adanya penandatangan perjanjian saja, namun dalam praktek di lapangan masih sangat sukar untuk dilakukan.

Lemahnya penerapan sanksi yang diterapkan apabila salah satu negara anggota tidak taat mengikuti dan melaksanakan hasil dari kesepakatan yang telah ada juga menjadi "boomerang" tersendiri bagi komitmen regional. Kemudian juga tidak adanya penghargaan bagi negara anggota yang telah melakukan kewajiban dari hasil kesepakatan berbagai isi perjanjian yang telah disepakati bersama, menjadikan sikap negara anggota masih kembali melihat pada kondisi dan kemampuan masing-masing kepentingan nasionalnya.

Dengan demikian, walaupun berbagai komitmen telah dibangun oleh pemerintah Indonesia pada lingkup internasional maupun regional, dan berbagai kebijakan telah diberlakukan oleh pemerintah secara nasional maupun di daerah, korban perdagangan manusia terutama perempuan dan anak masih mengalami peningkatan dari tahun ke tahun.

\section{Proses (Konversi) Formulasi Kebijakan Penanganan Trafficking di Indonesia}

Di Indonesia, pemerintah telah mengambil langkah-langkah strategis nasional melalui penyusunan dan penetapan: 1) Rencana Aksi Nasional Penghapusan Eksploitasi Seksual Komersial Anak dengan Keputusan Presiden Republik Indonesia Nomor 87 Tahun 2002, 2) Rencana Aksi Nasional Penghapusan Perdagangan Perempuan dan Anak (RAN P3A) dengan Keputusan Presiden Republik Indonesia Nomor 88 Tahun 2002 dan 3) Rencana Aksi Nasional Penghapusan Bentukbentuk Pekerjaan Terburuk untuk Anak dengan Keputusan Presiden Republik Indonesia Nomor 59 Tahun 2002. 
Pada tahun 2004, pemerintah Indonesia mengesahkanUndang-undangNomor39Tahun 2004 tentang Penempatan dan Perlindungan Tenaga Kerja Indonesia di Luar Negeri (UU PPTKILN). Pada 19 April 2007 telah disahkan kebijakan nasional anti Trafficking melalui Undang-undang Nomor 21 Tahun 2007 tentang Pemberantasan Tindak Pidana Perdagangan Orang (UU PTPPO) setelah hampir 10 tahun penantian sejak rancangan kebijakan tersebut dirumuskan. Kebijakan nasional tersebut kemudian diterjemahkan ke dalam berbagai peraturan daerah Penghapusan Perdagangan Perempuan dan Anak oleh Pemerintah Daerah di wilayahnya masing-masing di seluruh Indonesia.

Implementasi UU PTPPO merupakan sebuah prestasi karena kebijakan tersebut dianggap komprehensif dan mencerminkan ketentuan yang telah diatur di dalam Protokol Palermo. Indonesia sebagai salah satu negara yang menandatangani Protokol Palermo, mempunyai kesepakatan dengan dunia internasional tentang bagaimana melihat perdagangan manusia sebagai kasus yang multikompleks dan harus ditangani secara komprehensif, melalui lima langkah penting penanganan, yaitu: penindakan, pencegahan, rehabilitasi sosial, perlindungan bagi korban, kerjasama dan peran serta masyarakat ${ }^{23}$. Kemudian sesuai amanat pasal 45 UU PTPPO, telah ditetapkan pula Peraturan Kapolri Nomor 10 Tahun 2007 tentang Organisasi Tata Kerja Unit Pelayanan Perempuan dan Anak (UPPA) di Lingkungan Kepolisian Negara Republik Indonesia, dimana disediakannya Ruang Pelayanan Khusus sebagai tempat pelayanan UPPA tersebut.

UU PTPPO cukup sukar diterapkan dikarenakan pada proses pembuktian eksploitasi manusia yang tercantum pada pasal-pasal yang terkait di dalamnya, walaupun aturannya cukup tegas seperti hukuman penjara paling singkat tiga tahun dan paling lama 15 tahun dan

23 Moeri, Fasisaka, dan Resen. "Implementasi Protokol dalam Menanggulangi Permasalahan Tenaga Kerja Wanita Indonesia yang Menjadi Korban Human Trafficking”. pidana denda paling sedikit Rp.120.000.000,dan paling banyak Rp.600.000.000,-. Hasilnya, karena banyaknya kasus perdagangan manusia sukar dilakukan pembuktiannya, maka kasuskasus tersebut hanya dikenakan Pasal 296 Kitab Undang-undang Hukum Pidana yang hukumannya lebih ringan dibandingkan ketentuan hukuman pada UU PTPPO, yaitu hukumannya hanya satu tahun empat bulan hukuman pidana penjara.

Kompleksitas dalam penerapan UU PTPPO juga menghadapi kendala ketika para korban perdagangan manusia berada di luar negeri dan tempat terpencil, sehingga cukup sukar dalam menggali kesaksian para korban. Walaupun pemerintah telah mengupayakan dengan adanya 123 Pusat Layanan Terpadu (PPT) sebagai lembaga layanan korban kekerasan, tetapi para korban perdagangan manusia tidak memiliki informasi yang baik mengenai hal tersebut.

Pada tahun 2008, sesuai amanat pasal 58 UU PTPPO telah ditetapkan Peraturan Pemerintah Nomor 9 Tahun 2008 tentang Tata Cara dan Mekanisme Pusat Pelayanan Terpadu bagi Saksi dan/atau Korban Tindak Pidana Perdagangan Orang. Selain itu juga telah ditetapkan Peraturan Presiden Republik Indonesia Nomor 69 Tahun 2008 tentang Gugus Tugas Pencegahan dan Penanganan Tindak Pidana Perdagangan Orang. Untuk lingkungan Kapolri, ditetapkan pula Peraturan Kapolri Nomor 3 Tahun 2008 tentang Pembentukan Ruang Pelayanan Khusus dan Tata Cara Pemeriksaan Saksi dan/atau Korban Tindak Pidana Perdagangan Orang.

Sesuai dengan amanat Peraturan Pemerintah Nomor 9 Tahun 2008, juga telah ditetapkan Peraturan Menteri Negara Pemberdayaan Perempuan RI Nomor 1 Tahun 2009 tentang Standar Pelayanan Minimal Pelayanan Terpadu bagi Saksi dan/atau Korban Tindak Pidana Perdagangan Orang. Keputusan Presiden Republik Indonesia Nomor 87 dan 88 Tahun 2002 kemudian dievaluasi dan diterbitkan Peraturan Menteri Koordinator Bidang Kesejahteraan Rakyat Nomor 25 
Tahun 2009 tentang Rencana Aksi Nasional Pemberantasan Tindak Pidana Perdagangan Orang (PTPPO) dan Eksploitasi Seksual Anak (ESA) 2009-2014.

Selain itu, pemerintah Indonesia juga meratifikasi Konvensi Perserikatan Bangsa-bangsa Menentang Tindak Pidana Transnasional yang Terorganisasi dengan Undang-undang RI Nomor 5 Tahun 2009. Hal ini kemudian ditindaklanjuti dengan meratifikasi Protokol untuk Mencegah, Menindak dan Menghukum Perdagangan Orang, terutama Perempuan dan Anak-anak, dengan Undang-undang RI Nomor 14 Tahun 2009 tentang Pengesahan Protokol Mencegah, Menindak dan Menghukum Perdagangan Orang. Terdapat pula Undang-undang Nomor 15 Tahun 2009 tentang Pengesahan Protokol Menentang Penyelundupan Migran melalui Darat, Laut dan Udara.

Beberapa pengesahan yang telah diupayakan oleh pemerintah tentunya harus didukung oleh komponen hukum yang ada (aparat penegak hukum), antara lain kepolisian, kejaksaan, pengadilan dan lembaga pemasyarakatan. Artinya, keberadaan komponen-komponen hukum inipun diperlukan secara signifikan untuk menunjang keberadaan hukum bagi Indonesia dalam menjalankan proses penegakan hukum pemberantasan perdagangan manusia.

Komponen yang telah disebutkan tersebut menjadi indikator keberhasilan sebuah negara mengatasi perdagangan manusia, walaupun dibutuhkan peran masyarakat yang baik dalam menjalankan komponen tersebut. Ketika sebagian masyarakat banyak "menyalahkan" pemerintah, yang biasanya dikarenakan mereka bukan bagian dari komponen tersebut, maka apabila kasus perdagangan manusia meningkat, sesungguhnya yang menjadi penyebab terjadinya perdagangan manusia adalah dari masyarakat itu sendiri sebagai pihak yang dieksploitasi secara langsung. Sehingga keberhasilan komponen-komponen tersebut dalam mengatasi perdagangan manusia tidak dapat dipisahkan dari peran masyarakat itu sendiri.
Berbagai kegiatan penandatanganan dan proses ratifikasi instrumen hukum dan perjanjian HAM internasional yang dilakukan pemerintah Indonesia tersebut menunjukkan pemerintah Indonesia telah sepakat dan berupaya memenuhi tanggungjawabnya dalam mempromosikan, melindungi dan memenuhi HAM warga negaranya, tetapi kendala yang terjadi adalah penerapan berbagai hukum yang telah ada menghadapi keterbatasan kemampuan aparat hukum dan keberadaan korban perdagangan manusia yang berada di tempat yang jauh dan terpencil sehingga tidak mampu untuk melakukan penanganan terhadap korban.

\section{Kondisi Penanganan Kasus Trafficking di Indonesia}

Indonesia merupakan salah satu negara asal utama, yang pada tataran tertentu menjadi tujuan transit bagi laki-laki, perempuan maupun anak-anak untuk menjadi tenaga kerja paksa dan korban perdagangan manusia. Berdasarkan Laporan Tahunan Perdagangan Orang 2016 oleh Kedutaan Besar dan Konsulat AS di Indonesia, setiap provinsi di Indonesia merupakan daerah asal sekaligus daerah tujuan perdagangan manusia. Pemerintah memperkirakan sekitar 1,9 juta dari 4,5 juta warga Indonesia yang bekerja di luar negeri - umumnya perempuan - tidak memiliki dokumen atau telah tinggal melewati batas izin tinggal. Situasi tersebut meningkatkan kerentanan mereka terhadap perdagangan manusia ${ }^{24}$.

Masih berdasarkan Laporan Tahunan Perdagangan Orang 2016 oleh Kedutaan Besar dan Konsulat AS di Indonesia, jumlah pekerja migran Indonesia yang terjebak dalam situasi kerja paksa, termasuk terjebak jeratan hutang, baik di Asia, Timur Tengah maupun di kapalkapal penangkapan ikan, cukup signifikan. Malaysia tetap menjadi tujuan utama bagi pekerja migran Indonesia diikuti dengan Arab

24 US Embassy for Indonesia. 2016. "Laporan Tahunan Perdagangan Orang 2016”, diakses pada 8 Agustus 2017, Pukul 23:50 WITA, https://id.usembassy.gov/id/ourrelationship-id/official-reports-id. 
Saudi. Pemerintah memperkirakan lebih dari satu juta dari 1,9 juta pekerja Indonesia berstatus tak resmi berada di Malaysia. Warga negara Indonesia yang menjadi korban juga sudah teridentifikasi di negara-negara lainnya di Asia dan di Timur Tengah selama periode laporan - termasuk Korea Selatan - juga di Kepulauan Pasifik, Afrika, Eropa (termasuk Belanda dan Turki), serta Amerika Selatan. Perempuan Indonesia baik dewasa maupun di bawah umur juga menjadi korban perdagangan seks terutama di Malaysia, Taiwan, dan Timur Tengah. Para ahli melaporkan bahwa perluasan penggunaan dokumen perjalanan biometrik dari pemerintah yang mengakibatkan dokumen perjalanan palsu lebih sulit diperoleh telah menyebabkan lebih banyak pekerja tanpa dokumen resmi (undocumented) melakukan perjalanan ke luar negeri lewat jalur laut.

Lembaga-lembaga Swadaya Masyarakat (LSM) memperkirakan perekrut tenaga kerja bertanggungjawab atas lebih dari setengah kasus perdagangan perempuan Indonesia di luar negeri. Seiring meningkatnya kesadaran masyarakat tentang perdagangan manusia, pemerintah dan LSM memberikan perhatian lebih pada pelaku perdagangan manusia yang merekrut lebih banyak korban dari provinsiprovinsi di wilayah timur Indonesia, dimana kesadaran atas kasus ini lebih rendah. Pekerja migran seringkali berhutang kepada perekrut buruh independen di luar negeri maupun perusahaan rekrutmen lokal. Hal ini membuat mereka semakin rentan terhadap jeratan hutang. Beberapa perusahaan memanfaatkan jerat hutang, menahan dokumen, serta memberikan ancaman kekerasan agar mereka dapat tetap dipekerjakan secara paksa. Dalam beberapa kasus, pejabat yang korup memfasilitasi penerbitan dokumen palsu, menerima suap yang memungkinkan "broker" mengirim pekerja migran menyeberangi perbatasan tanpa dokumen resmi, melindungi tempat dimana perdagangan seks terjadi, pengawasan yang lemah dari penyalur jasa tenaga kerja, menghalangi penegakan hukum dan proses peradilan untuk menahan pelaku yang bertanggungjawab atas perdagangan manusia ${ }^{25}$.

Buruh migran atau tenaga kerja di luar negeri adalah salah satu dimana perdagangan manusia terjadi. Sebagian besar buruh migran mendapat pekerjaan di negara lain melalui proses resmi dan proses yang tidak resmi. Sebagian dari kekerasan yang mereka hadapi adalah ${ }^{26}$ :

a. Calo memberikan surat-surat palsu untuk mempercepat proses atau membuat anak kelihatan lebih tua agar dapat bekerja. Hal ini memberikan resiko kepada buruh migran di negara dimana mereka bekerja.

b. Sebagian besar buruh migran berhutang pada perantara atau PJTKI karena mereka tidak mampu membayar biaya resmi dan tidak resmi yang dibebankan pada mereka sejak awal. PJTKI mengenakan biaya seperti biaya imigrasi, pemeriksaan medis dan akomodasi saat mereka sedang menunggu penempatan di luar negeri kepada buruh migran. Maka dari itu, sebagian dari buruh migran tidak pernah menerima gaji mereka dan diberitahukan bahwa gaji mereka dipergunakan untuk membayar hutang.

c. Majikan atau calo menyimpan paspor korban dan surat-surat lainnya sehingga tidak memungkinkan korban untuk pergi atau mencari kebebasan.

d. Kondisi kerja mengenaskan dan seringkali melanggar Undang-undang ketenagakerjaan setempat.

Bagan berikut ini menunjukkan saling keterhubungan antara migrasi tak teratur, perdagangan dan penyelundupan yang dikutip dari buku Mencegah Diskriminasi, Eksploitasi dan Perlakuan Sewenang-wenang terhadap Pekerja Migran Perempuan: Pedoman Informasi Buku 6 Perdagangan Perempuan dan Anak Perempuan oleh Program Promosi Gender Organisasi Perburuhan Internasional ${ }^{27}$ :

US Embassy for Indonesia, "Laporan Tahunan Perdagangan Orang 2016".

26 ACILS dan ICMC, Pendampingan Korban Perdagangan Manusia dalam Proses Hukum di Indonesia: Sebuah Panduan untuk Pendamping Korban (Jakarta, 2004), 8.

27 Amiruddin, "Wilayah Tertinggal, Migrasi dan Perdagangan Manusia" 14. 
Bagan 1. Keterhubungan Migrasi Tak Teratur, Perdagangan dan Penyelundupan

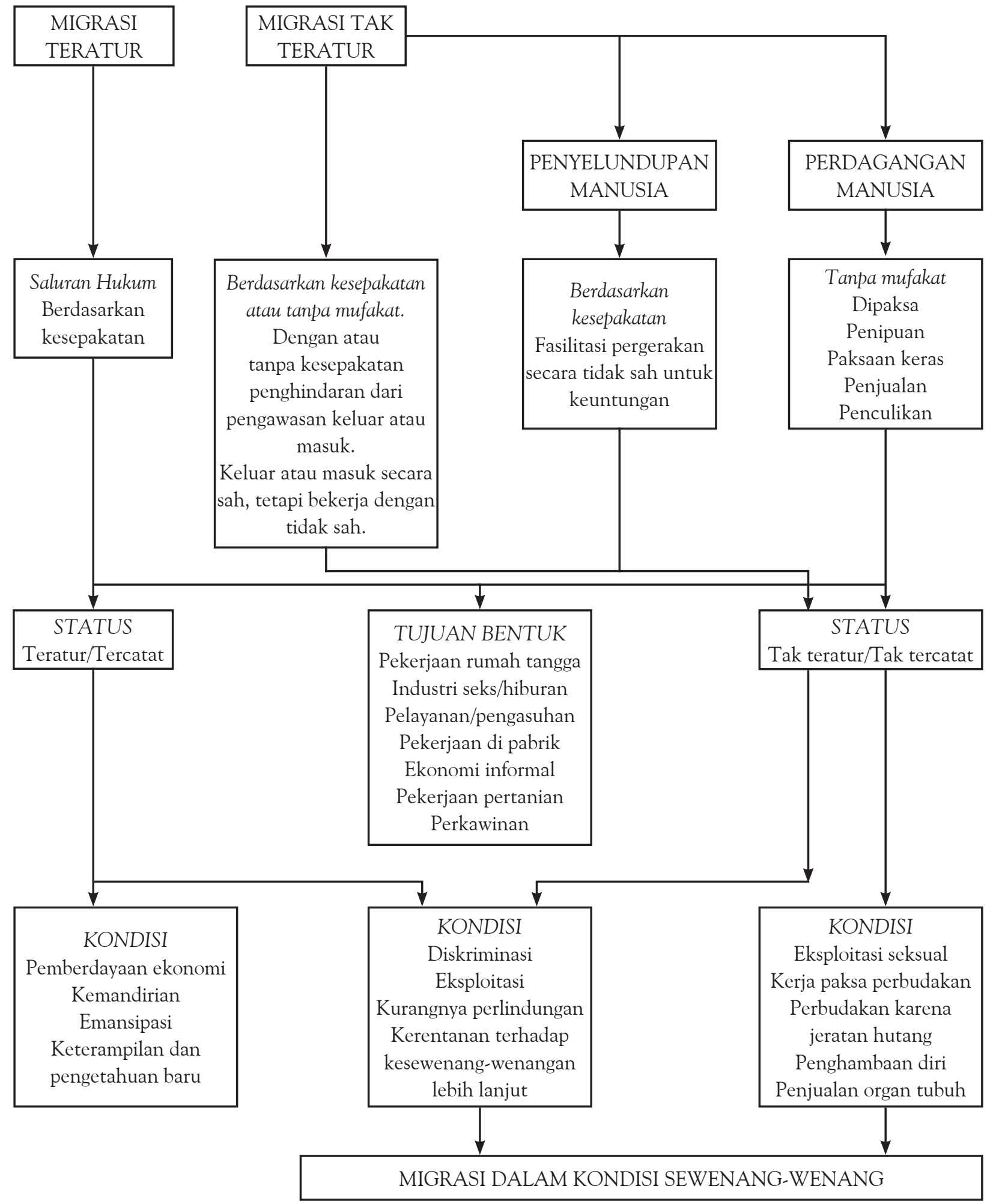

Sumber: Amiruddin, 2008:14.

Pemerintah Indonesia juga belum Indonesia, pemerintah telah menghukum 199 sepenuhnya mematuhi standar minimum pelaku perdagangan manusia, memulangkan penghapusan perdagangan manusia, namun 5.668 Warga Negara Indonesia yang pemerintah sedang melakukan upaya-upaya teridentifikasi sebagai korban perdagangan signifikan untuk mematuhinya. Berdasarkan manusia di luar negeri, serta menyediakan Laporan Tahunan Perdagangan Orang 2016 tempat perlindungan sementara dan oleh Kedutaan Besar dan Konsulat AS di memberikan pelayanan untuk lebih dari 441 
korban perdagangan manusia. Pemerintah menghukum delapan pelaku perdagangan manusia yang terlibat kasus kerja paksa di kapal penangkap ikan, namun pemerintah tidak mengajukan tuntutan terhadap kejahatan perdagangan manusia dalam industri perikanan lainnya, meskipun lebih dari 1.500 kru kapal telah teridentifikasi sebagai korban perdagangan manusia. Pemerintah telah membuat delapan penampungan baru untuk melayani korban kriminal, termasuk perdagangan manusia, tapi kualitas dan layanan penampungan tersebut berbeda di setiap wilayah.

Kurangnya pengetahuan pejabat tentang indikator dan perundang-undangan antiperdagangan manusia menyebabkan lemahnya tindakan proaktif terhadap identifikasi korban di kalangan populasi yang rentan serta upaya pelaksanaan Undang-undang anti-perdagangan manusia serta koordinasi yang tidak memadai antar institusi pemerintah telah menghambat implementasi strategi anti-perdagangan manusia secara nasional. Maraknya praktik korupsi diantara para penegak hukum juga telah menghambat upaya pemberantasan perdagangan manusia dan memungkinkan pelaku memiliki imunitas dalam melakukan kejahatannya. Penegak hukum hanya menuntut satu pejabat atas kejahatan perdagangan manusia $^{28}$.

Unit Anti Perdagangan Orang Badan Reserse Kriminal Kepolisian Negara Republik Indonesia menyebutkan 221 penyelidikan kasus baru selama tahun 2015 mengalami penurunan dibandingkan tahun sebelumnya yang berjumlah 305 kasus. Pihak kepolisian menyerahkan 165 kasus untuk tahap penuntutan lebih tinggi dibandingkan 134 kasus pada tahun 2014, namun tidak diketahui berapa jumlah penuntutan yang sudah dilakukan. Mahkamah Agung menjatuhkan hukuman kepada 119 terpidana di tahun 2015, dengan hukuman penjara bervariasi antara tiga sampai 15 tahun, meningkat dari 79 terpidana pada tahun 2014. Kurangnya pemahaman atas UU PTPPO

US Embassy for Indonesia, "Laporan Tahunan Perdagangan Orang 2016". menyebabkan sebagian penuntut umum dan hakim menolak kasus atau memakai hukum lain untuk menuntut pelaku perdagangan manusia ${ }^{29}$.

Masih berdasarkan Laporan Tahunan Perdagangan Orang 2016 oleh Kedutaan Besar dan Konsulat AS di Indonesia, disebutkan bahwa sebuah organisasi internasional bersama pemerintah telah mengidentifikasi sekitar 1.500 laki-laki yang dieksploitasi menjadi pekerja paksa di sektor perikanan. Sebuah LSM juga berhasil mengidentifikasi 97 korban pekerja paksa, dimana 80 diantaranya menjadi pekerja rumah tangga, 10 pekerja pabrik, dan tujuh pekerja perkebunan. Organisasi internasional yang sama menyediakan pula layanan untuk 1.322 korban perdagangan manusia yang dirujuk oleh institusi pemerintah, LSM, para pengacara, dan kedutaan besar negara asing. LSM kemudian menyerahkan lebih dari 1.126 dari korban tersebut kembali ke penampungan dan penyedia pelayanan kesehatan. Penampungan-penampungan tersebut sebagian besar dijalankan oleh pemerintah atau menerima dana dari pemerintah.

Sistem pemerintah yang memungkinkan pekerja migran untuk mengajukan pengaduan telah menerima 462 laporan tentang perdagangan manusia dan 948 laporan penyalahgunaan atau perselisihan di tempat kerja, sebagian dari itu kemungkinan terkait perdagangan manusia. Ketika laporan tersebut mengarah ke identifikasi korban perdagangan manusia, badan pemerintah yang bertanggungjawab menempatkan dan melindungi pekerja Indonesia di luar negeri menyerahkan kasus tersebut ke kantor polisi Indonesia setempat dimana perdagangan manusia itu terjadi atau daerah asal korban. Namun tidak jelas apakah upaya tersebut berhasil mengarah ke penyelidikan kasus perdagangan manusia. Pejabat konsulat Indonesia memeriksa para pekerja migran untuk mengetahui kemungkinan mereka merupakan korban perdagangan manusia, kemudian

US Embassy for Indonesia, "Laporan Tahunan Perdagangan Orang 2016". 
menyediakan penampungan dan bantuan finansial kepada korban. Kementerian Luar Negerimemulangkan 5.668 korban perdagangan manusia asal Indonesia, peningkatan jumlah yang signifikan dari jumlah sebelumnya sekitar 1.200 korban yang dipulangkan pada tahun 2014. Kementerian Luar Negeri menawarkan penampungan untuk jangka-pendek dan layanan untuk korban saat pemulangan, untuk kemudian mereka diserahkan ke pemerintah daerah guna penanganan lebih lanjut ${ }^{30}$.

Bulan Agustus 2015, kepolisian Indonesia dan Arab Saudi bekerjasama menginspeksi penampungan TKI ilegal di Riyadh dan menemukan 39 pekerja rumah tangga yang dijanjikan pekerjaan di Bahrain namun kemudian dipaksa bekerja secara ilegal di Arab Saudi. Mereka menangkap tersangka pelaku, memulangkan kembali semua korban dan menyediakan layanan untuk pemulangan. Pada bulan September 2015, pemerintah Indonesia menandatangani nota kesepahaman dengan Uni Emirat Arab (UEA) untuk memfasilitasi investigasi bersama terkait jaringan perdagangan manusia, pertukaran informasi tentang penegakan Undang-undang anti-perdagangan manusia, dan memberikan akses penuh kepada pejabat Indonesia untuk menemui korban perdagangan manusia di UEA. Meskipun kurangnya pemahaman mengenai perdagangan manusia dan Undangundang anti-perdagangan manusia di kalangan penegak hukum dan peradilan, diketahui belum ada laporan penyelenggaraan atau pendanaan pelatihan anti-perdagangan manusia untuk para pejabat pemerintah. ${ }^{31}$

Pada November 2015, Kementerian Ketenagakerjaan untuk pertama kalinya meluncurkan 18 pusat layanan di desa-desa asal pekerja migran untuk meningkatkan antisipasi warga terhadap perdagangan manusia. Pusatpusat layanan ini mendapat bantuan dana dan sumber daya manusia dari pemerintah untuk menyediakan materi kampanye anti-

\footnotetext{
30 US Embassy for Indonesia, "Laporan Tahunan Perdagangan Orang 2016".

$31 \quad$ US Embassy for Indonesia, "Laporan Tahunan Perdagangan Orang 2016".
}

perdagangan manusia bagi calon TKI, program pemberdayaan ekonomi bagi kaum muda yang berisiko, serta perawatan dan layanan-layanan lain untuk korban perdagangan manusia yang kembali ke tanah air, termasuk menyediakan jalur telepon khusus untuk pekerja migran agar dapat melaporkan pelanggaran-pelanggaran yang terjadi seperti praktek kerja paksa. Kementerian Ketenagakerjaan juga telah mencabut atau menunda izin dari 24 perusahaan yang diduga terlibat dalam perekrutan ilegal, namun tidak diketahui berapa jumlah agen tenaga kerja yang sudah dilaporkan kepada pihak kepolisian untuk penyelidikan dan tidak diketahui apakah kepolisian sudah memulai penyelidikan. Pihak berwenang melakukan razia terhadap perusahaan perekrutan yang diduga melakukan pelanggaran namun tidak ada laporan soal hukuman yang diberikan untuk tindakan ilegal tersebut.

Berhubung banyak kasus pekerja rumah tangga Indonesia yang menjadi korban perdagangan manusia di Timur Tengah, pemerintah Indonesia memperluas moratorium izin bekerja bagi pekerja rumah tangga dari lima menjadi 21 negara di Afrika Selatan dan Timur Tengah. Pemerintah telah melakukan upaya-upaya untuk mengurangi permintaan atas pekerja paksa dan pekerja seks komersial serta telah menyediakan pelatihan anti-perdagangan manusia untuk personil militer sebelum bertugas ke luar negeri untuk misi perdamaian internasional dan misi diplomatik. Pemerintah juga menyediakan modul identifikasi korban perdagangan manusia dan perlindungan pekerja migran Indonesia di luar negeri. Namun, pemerintah tidak melaporkan tuntutan atau hukuman apapun terhadap wisatawan seks anak. ${ }^{32}$

\section{Implementasi Kebijakan Anti Trafficking beserta Faktor-faktor yang Mempengaruhinya}

Kebijakan atau policy dipergunakan untuk menunjuk perilaku seorang aktor (misalnya seorang pejabat, suatu kelompok, maupun suatu

32 US Embassy for Indonesia, "Laporan Tahunan Perdagangan Orang 2016". 
lembaga pemerintah) atau sejumlah aktor dalam suatu bidang kegiatan tertentu, keterlibatan aktor-aktor dalam perumusan kebijakan kemudian inilah yang menjadi ciri khusus dari kebijakan publik dalam suatu sistem politik. Sementara masalah implementasi kebijakan publik sangat mendasar dalam kehidupan masyarakat karena implementasilah yang menentukan "siapa memperoleh apa" dalam masyarakat. Proses serta perumusan kebijakan tidak berakhir apabila telah ditetapkan, karena baik tidaknya atau tepat tidaknya suatu kebijakan yang telah ditetapkan akan terbukti dari hasilhasil yang diperoleh dalam implementasinya.

Van Meter dan Van Horn merumuskan proses implementasi sebagai tindakan-tindakan yang dilakukan, baik oleh individu-individu (pejabat) atau kelompok pemerintah atau swasta yang diarahkan pada tercapainya tujuantujuan yang telah digariskan dalam keputusan kebijakan ${ }^{33}$.

Secara umum, suatu kebijakan dianggap berkualitas dan mampu dilaksanakan bila mengandung beberapa elemen ${ }^{34}$, yaitu:

a. Tujuan yang ingin dicapai atau alasan yang dipakai untuk mengadakan kebijakan itu, dimana tujuan suatu kebijakan dianggap baik apabila tujuannya:

1. Rasional, yaitu tujuan dapat dipahami atau diterima oleh akal yang sehat. Hal ini terutama dilihat dari faktorfaktor pendukung yang tersedia, dimana suatu kebijakan yang tidak mempertimbangkan faktor pendukung tidak dapat dianggap sebagai kebijakan yang rasional.

2. Diinginkan (desirable), yaitu tujuan dari kebijakan menyangkut kepentingan orang banyak sehingga mendapat dukungan dari banyak pihak.

b. Asumsi yang dipakai dalam proses perumusan kebijakan itu realistis, asumsi tidak mengada-ada. Asumsi juga

33 Solichin Abdul Wahab, Analisis Kebijakan dari Formulasi ke Implementasi Kebijaksanaan Negara, Jakarta: Bumi Aksara, 2008), 65.

34 Said Zainal Abidin, Kebijakan Publik (Jakarta: Yayasan Pancur Siwak, 2002), 76. menentukan tingkat validitas suatu kebijakan.

c. Informasi yang digunakan cukup lengkap dan benar, dimana suatu kebijakan menjadi tidak tepat jika didapatkan dari informasi yang tidak benar atau sudah kadaluwarsa.

Dalam kaitannya dengan implementasi kebijakan anti perdagangan manusia di Indonesia, salah satunya melalui UU PTPPO, dapat diketahui bahwa elemen kebijakan tersebut memiliki tujuan yang rasional dan diinginkan karena desakan kebutuhan akan penanganan kasus perdagangan manusia yang perkembangannya semakin tinggi dari tahun ke tahun, terdapat dasar asumsi yang realistis pula dan informasi yang cukup lengkap dan benar bahwa terdapat korban perdagangan manusia dan terjadinya praktek-praktek penyalahgunaan wewenang oleh berbagai pihak yang terkait dengan perekrutan hingga penempatan tenaga kerja Indonesia.

Berdasarkan teori George C. Edward III, implementasi kebijakan dipengaruhi oleh empat variabel, yaitu:

1. Komunikasi, yaitu proses penyampaian informasi oleh komunikator kepada komunikan. Sementara itu, komunikasi kebijakan berarti merupakan proses penyampaian informasi kebijakan dari pembuat kebijakan (policy makers) kepada pelaksana kebijakan (policy implementors). Informasi perlu disampaikan kepada pelaku kebijakan agar pelaku kebijakan dapat memahami apa yang menjadi isi, tujuan, arah, kelompok sasaran (target group) kebijakan, sehingga pelaku kebijakan dapat mempersiapkan hal-hal apa saja yang berhubungan dengan pelaksanaan kebijakan agar proses bisa berjalan dengan efektif serta sesuai dengan tujuan kebijakan itu sendiri.

2. Sumber daya, berkaitan dengan segala sumber yang dapat digunakan untuk mendukung keberhasilan implementasi kebijakan. Sumber daya mencakup sumber daya manusia, anggaran, fasilitas, informasi dan kewenangan. Bagaimanapun jelas 
dan konsistensinya ketentuan-ketentuan dan aturan-aturan, jika para pelaksana kebijakan yang bertanggungjawab untuk melaksanakan kebijakan kurang mempunyai sumber-sumber daya untuk melaksanakan kebijakan secara efektif, maka implementasi kebijakan itu tidak akan efektif.

3. Disposisi, adalah kecenderungan perilaku atau karakteristik dari pelaksana kebijakan yang berperan penting untuk mewujudkan implementasi kebijakan yang sesuai dengan tujuan atau sasaran. Sikap dari pelaksana kebijakan akan sangat berpengaruh dalam implementasi kebijakan. Apabila implementor memiliki sikap yang baik, maka dia akan dapat menjalankan kebijakan dengan baik, sebaliknya apabila sikapnya tidak mendukung maka implementasi tidak akan terlaksana dengan baik.

4. Struktur birokrasi, melingkupi dua hal yaitu mekanisme dan struktur birokrasi itu sendiri. Struktur organisasi memiliki pengaruh yang signifikan terhadap implementasi kebijakan ${ }^{35}$.

Sedangkan menurut David L. Weimer dan Aidan R. Vining, keberhasilan implementasi suatu program (kebijakan) dipengaruhi oleh tiga kelompok variabel besar sebagai berikut:

1. Logika kebijakan, hal ini dimaksudkan agar suatu kebijakan yang ditetapkan masuk akal (reasonable) dan mendapat dukungan teoritis.

2. Lingkungan tempat kebijakan dioperasikan, hal ini akan mempengaruhi keberhasilan implementasi suatu kebijakan. Dalam hal ini mencakup lingkungan sosial, politik, ekonomi, dan fisik atau geografis. Suatu kebijakan yang berhasil pada suatu daerah, bisa saja gagal diimplementasikan pada daerah lain yang berbeda.

3. Kemampuan implementor kebijakan. Tingkat kompetensi implementor mempengaruhi keberhasilan implementasi suatu kebijakan ${ }^{36}$.

35 Widodo, Analisis Kebijakan Publik: Konsep dan Aplikasi Analisis Proses Kebijakan Publik, 96-110.

36 Subarsono, Analisis Kebijakan Publik (Konsep, Teori dan Aplikasi), 103.
Implementasi kebijakan anti perdagangan manusia di Indonesia dalam upaya melindungi tenaga kerja Indonesia, terutama perempuan dan anak-anak dapat dikaji berdasarkan kedua teori tersebut di atas untuk melihat keberhasilannya.

Pemerintah Indonesia memiliki kelemahan dalam sistem pelaporan dan pengumpulan data dalam upaya penegakan Undang-undang Nomor 21 Tahun 2007 tentang Pemberantasan Tindak Pidana Perdagangan Orang (UU PTPPO) yang komprehensif. Penerapan UU PTPPO untuk menuntut kejahatan yang bukan termasuk kategori perdagangan manusia, seperti penyelundupan, melemahkanpenentuanjumlah total investigasi, penuntutan, dan penangkapan. Pemerintah Indonesia mempertahankan upaya penegakan Undang-undang anti-perdagangan manusia melalui UU PTPPO yang melarang semua bentuk perdagangan manusia dan menetapkan hukuman penjara mulai dari tiga hingga 15 tahun. Hukuman tersebut cukup berat dan sepadan dengan hukuman yang ditetapkan untuk pidana berat lainnya, seperti pemerkosaan. Namun, pejabat pemerintah menyebutkan adanya koordinasi yang tidak efektif antara polisi, jaksa penuntut umum, dan hakim yang menyulitkan penyelidikan, penuntutan, dan penangkapan pelaku perdagangan manusia, terutama untuk kasus yang melibatkan beberapa wilayah hukum, termasuk di negara lain.

Pihak kepolisian dan jaksa masih belum mampu beradaptasi secara efektif dengan UU PTPPO dikarenakan alasan panjangnya persiapan untuk mempersiapkan kasus penuntutan terhadap kasus perdagangan manusia untuk menghukum pelaku perdagangan manusia, sehingga beberapa jaksa dan hakim masih menggunakan hukum yang lebih lazim untuk menuntut pelaku perdagangan manusia. Mediasi di luar hukum dapat menghambat keberhasilan tuntutan untuk berhasil, karena keluarga korban, yang telah menerima pembayaran dari pelaku perdagangan manusia, biasanya tidak menginginkan proses hukum resmi. 
Pasifnya pihak kepolisian dalam menyelidiki pengaduan perdagangan manusia juga terlihat dari beberapa kegagalan untuk menangkap dan mengejar pelaku perdagangan manusia yang sering melarikan diri ke daerah lain atau bahkan ke luar negeri. Kegagalan intervensi terlihat dalam menangkap orang yang mungkin pelaku perdagangan manusia, yang sebenarnya juga merupakan upaya melindungi korban, seperti masih adanya anak-anak dalam pelacuran.

LSM dan pejabat pemerintah melaporkan perilaku korupsi yang endemis di kalangan institusi keamanan dan otoritas lainnya yang terus menghambat upaya penegakan UU PTPPO. Selama periode Laporan Tahunan Perdagangan Orang 2016 yang dilakukan Kedutaan Besar dan Konsulat AS di Indonesia, polisi menangkap pejabat lokal di Batam atas dugaan eksploitasi seorang gadis pekerja rumah tangga dari Jawa Barat, dimana pihak berwenang melaporkan bahwa penangkapan tersebut merupakan yang pertama terhadap pejabat Batam karena kejahatan perdagangan manusia, dan penuntutan sedang berlangsung di akhir periode laporan ${ }^{37}$.

Persoalan oknum pejabat pemerintah masih berkaitan pada saat pelayanan penerbitan paspor yang masih menjadi obyek korupsi, hal ini teridentifikasi pada bulan April 2011 yaitu tertangkapnya wakil PJTKI karena memalsukan dokumen dua pekerja rumah tangga Indonesia yang dikirim oleh suatu agen ke Arab Saudi, sehingga masih adanya beberapa pejabat yang masih menfasilitasi perdagangan manusia. Agen perekrutan juga terlibat dalam persoalan memalsukan tanggal lahir dalam rangka mengurus paspor dan dokumen pekerja migran. Keterlibatan mereka karena mempunyai kaitan dengan para pejabat korupsi, sehingga mereka juga cukup mudah mengeluarkan Kartu Tanda Penduduk nasional dan data Kartu Keluarga bagi anak-anak untuk diperdagangkan baik di dalam maupun di luar negeri.

Berdasarkan Laporan Tahunan Perdagangan Orang 2016, pemerintah Indonesia belum

$37 \quad$ US Embassy for Indonesia, "Laporan Tahunan Perdagangan Orang 2016". mengerahkan upaya identifikasi dan perlindungan korban perdagangan manusia yang memadai secara berkelanjutan, walaupun telah berusaha untuk mengumpulkan data layanan korban dari berbagai LSM.Pejabatberwenang tidak mengumpulkan atau melaporkan data korban yang telah teridentifikasi secara komprehensif. Meski pemerintah memiliki prosedur operasional standar untuk secara proaktif mengidentifikasi korban, namun pemerintah tidak menerapkannya pada kelompok rentan secara konsisten. Pemerintah masih tetap mengandalkan pada organisasi internasional dan LSM untuk inspeksi korban, terutama korban warga asing di Indonesia.

Kementerian Sosial tetap menyediakan layanan trauma dan dilaporkan menyediakan penampungan darurat untuk korban kriminal, termasuk korban perdagangan manusia di pusat rehabilitasi orang dewasa, tempat perlindungan anak, dan pusat perawatan trauma. Pemerintah juga telah membangun delapan penampungan baru untuk perawatan trauma sepanjang tahun 2016, dengan jumlah total 26. Pemerintah mengelola 247 pusat layanan, didukung oleh dana pemerintah dan swasta serta lebih banyak dijalankan oleh pemerintah provinsi yang melayani populasi rentan, termasuk korban perdagangan manusia. Beberapa penampungan menyediakan perawatan jangka panjang, termasuk dana untuk memulai usaha kecil. Beberapa korban perdagangan manusia telah ditempatkan di 13 "rumah detensi" yang dikelola oleh pemerintah. Meskipun demikian, pemerintah Indonesia telah bekerjasama dengan organisasi internasional untuk memperbaiki kualitas dan layanan penampungan. Sebuah organisasi internasional melaporkan bahwa korban perdagangan manusia seringkali tidak mengetahui bahwa layanan reintegrasi dan lanjutan untuk korban yang sudah meninggalkan penampungan masih belum memadai.

Kementerian Kesehatan bertanggung jawab atas pembiayaan perawatan kesehatan korban, dan rumah sakit-rumah sakit yang dikelola kepolisian berkewajiban untuk menyediakan perawatan medis gratis. LSM dan 
pejabat pemerintah melaporkan beberapa staf rumah sakit tidak menyadari kewajiban ini atau tidak berniat memberikan perawatan tanpa kompensasi. Selama periode laporan, lembaga perlindungan saksi pemerintah memberikan bantuan hukum untuk sekurang-kurangnya 88 korban, sebab ada beberapa agensi yang menyediakan bantuan hukum sehingga jumlah total yang menerima bantuan tersebut tidak diketahui. Undang-undang mengizinkan korban untuk memperoleh ganti rugi dari pelaku perdagangan manusia dan setidaknya 25 korban telah menerima kompensasi sepanjang tahun 2015. Tidak ada laporan dari pemerintah tentang korban yang dihukum karena tindakan kriminal yang dilakukannya saat menjadi korban perdagangan manusia, namun upaya yang tidak memadai untuk memeriksa kelompok yang rentan sesuai indikator kejahatan perdagangan manusia, termasuk saat razia penangkapan orang-orang dalam bisnis prostitusi atau pemberantasan penangkapan ikan secara ilegal, dapat mengakibatkan korban-korban yang tidak teridentifikasi terkena proses hukum. Pemerintah tidak menyediakan alternatif hukum untuk korban asing yang dipindahkan ke negara lain dimana mereka mungkin menghadapi kesulitan atau masalah hukuman.

Pemerintah melakukan upaya minimal untuk mencegah perdagangan manusia. Sebagian besar upaya pencegahan dilakukan di tingkat kabupaten/kota dan provinsi; pendanaan dan kegiatan dilakukan oleh satuan tugas yang berbeda-beda di tiap wilayah. Gugus tugas nasional anti-perdagangan orang (TPPO), di bawah naungan Kementerian Pemberdayaan Perempuan dan Perlindungan Anak (KPPPA), melakukan beberapa kali pertemuan selama periode laporan dan mengadopsi Rencana Aksi Nasional (RAN) 2015-2019 untuk memberantas perdagangan manusia. Pertemuan-pertemuan dan RAN berfokus pada peningkatan layanan rehabilitasi dan reintegrasi untuk para korban serta memperbaiki koordinasi antara kementerian pemerintah dengan pemangku kepentingan lainnya. Dengan dukungan lembaga donor internasional dan LSM,
KPPPA dan pemerintah daerah merancang kampanye sadar perdagangan manusia untuk menginformasikan warga tentang praktik imigrasi dan prosedur rekrutmen yang aman. Sebagai tambahan, KPPPA telah mendirikan 25 satuan tugas anti-perdagangan manusia baru di tingkat daerah dan bersama LSM, menyediakan pelatihan berbasis profesi serta beasiswa untuk perempuan dan anak usia sekolah yang tinggal di komunitas yang menjadi sasaran perekrutan guna mengurangi kerentanan mereka terhadap perdagangan manusia. Namun demikian, Gugus Tugas TPPO masih kekurangan dana operasional dan masih bergantung pada kontribusi dana kementerian terkait. Kurangnya dana pada satuan tugas di daerah serta lemahnya koordinasi internal serta koordinasi satgas pada tingkat daerah dan nasional seringkali menghambat upaya anti-perdagangan manusia. KPPPA dan pemerintah daerah mendapat dukungan dana dari lembaga donor internasional dan LSM untuk merancang dan melaksanakan kampanye untuk meningkatkan kesadaran terhadap perdagangan manusia guna menginformasikan warga tentang praktik imigrasi dan prosedur rekrutmen yang aman.

Berdasarkan Laporan Pelaksanaan Pencegahan dan Penanganan Tindak Pidana Perdagangan Orang (TPPO) Tahun 201038, disebutkan bahwa tantangan yang dihadapi dalam penegakan hukum sebagai upaya pemberantasan TPPO antara lain:

1) Belum optimalnya pencegahan segala bentuk TPPO;

2) Belum optimalnya pelayanan kesehatan bagi korban TPPO dan ESA sesuai standar pelayanan minimal;

3) Belum optimalnya pelayanan rehabilitasi dan reintegrasi sosial terhadap korban perdagangan manusia;

4) Belum maksimalnya pengembangan norma hukum dan penegakan hukum;

38 Zulbahary, "Menilai Dampak Kebijakan Anti Trafficking di Indonesia terhadap HAM Kelompok Rentan dan Korban”, 58. 
5) Belum optimalnya kerjasama dan koordinasi;

6) Terbatasnya dukungan anggaran untuk upaya pencegahan dan penanganan TPPO dan ESA, baik di tingkat nasional maupun di tingkat daerah;

7) Masih banyak korban yang tidak mau melapor;

8) Aparat penegak hukum yang belum satu persepsi tentang TPPO dan ESA.

Dalam kaitannya dengan konsepsi implementasi kebijakan publik berdasarkan teori George C. Edward III, maka implementasi kebijakan anti perdagangan manusia di Indonesia, dipengaruhi oleh empat variabel. Pertama, masih lemahnya komunikasi antara para pelaksana kebijakan maupun komunikasi antara pemerintah dengan masyarakat, yang mengakibatkan para pelaksana kebijakan belum sepenuhnya mengetahui dan memahami bagaimana melakukan penindakan, pencegahan dan perlindungan korban perdagangan manusia secara komprehensif, serta mengakibatkan terjadinya distorsi implementasi sebab kelompok sasaran (masyarakat dan korban perdagangan manusia) belum sepenuhnya memiliki pengetahuan, kesadaran dan kepedulian terhadap dampak perdagangan manusia. Kedua, kesiapan dan kompetensi para pelaksana kebijakan masih membutuhkan persiapan yang lebih baik agar implementasi kebijakan dapat berjalan efektif. Untuk itu, dibutuhkan pengembangan pengetahuan dan keahlian bagi para pelaksana kebijakan, termasuk pejabat-pejabat publik yang terkait. Ketiga, diperlukannya disposisi yang lebih baik diantara para pelaksana kebijakan agar tercipta kecenderungan yang lebih baik dari para pelaku kebijakan untuk melaksanakan kebijakan anti perdagangan manusia yang efektif. Keempat, diperlukannya koordinasi dan pembagian kerja yang lebih baik pada unit-unit kerja yang terlibat di dalam implementasi kebijakan anti perdagangan manusia itu sendiri.

Namun variabel lainnya, yang dikemukakan oleh David L. Weimer dan Aidan R. Vining, yaitu lingkungan tempat kebijakan dioperasikan, turut menjadi variabel yang berpengaruh bagi implementasi kebijakan anti perdagangan manusia di Indonesia. Sebab bagaimanapun keberhasilan negara lain dalam menangani permasalahan perdagangan manusia melalui kebijakannya masing-masing yang berlandaskan pada berbagai komitmen internasional dan regional tentang perdagangan manusia, tidak dapat disamakan dengan kondisi di Indonesia. Perbedaan lingkungan sosial, politik, ekonomi, fisik atau geografis dan kondisi masyarakat, memegang peranan yang besar di dalam implementasi kebijakan anti perdagangan manusia tersebut.

Berdasarkan perkembangan yang terjadi di Indonesia berkenaan dengan kasus-kasus perdagangan manusia beserta upaya-upaya pencegahan dan penindakannya hingga kini, diperlukan rumusan upaya yang strategis sebagai berikut:

1. Memperluas kampanye tentang peningkatan kesadaran yang ditujukan untuk publik dan pemerintahan di seluruh daerah, terutama di berbagai wilayah yang memiliki kasus perdagangan manusia yang tinggi;

2. Memantau biaya rekrutmen yang dikenakan oleh agen-agen perekrutan tenaga kerja untuk memastikan bahwa kegiatan tersebut sudah sejalan dengan hukum;

3. Meningkatkan kesadaran para korban tentang pelayanan pemerintah yang terintegrasidalam penanganan perdagangan manusia;

4. Mengembangkan serta mengimplementasikan prosedur untuk mengidentifikasi korban potensial diantara kelompok yang rentan, termasuk memulangkan pekerja migran, pekerja prostitusi, termasuk anggota kru kapal penangkap ikan;

5. Memberikan pelatihan untuk pengawas pekerja terkait identifikasi korban dan prosedur penyerahannya;

6. Meningkatkan SDM anggota satuan tugas anti-perdagangan manusia serta memperbaiki koordinasi antar kementerian; 
7. Meningkatkan upaya-upaya untuk investigasi, menuntut, dan menjatuhkan hukuman terhadap agen perekrutan tenaga kerja, broker atau calo, dan pejabat publik korup yang terlibat dalam perdagangan manusia; dan

8. Menyusun protokol nasional yang menjelaskan tanggungjawab penuntutan kasus perdagangan manusia yang terjadi di luar provinsi tempat tinggal korban.

\section{KESIMPULAN}

Perdagangan manusia yang terjadi di Indonesia terjadi karena banyak faktor, antara lain kondisi dari masyarakat yang belum sepenuhnya sadar, peduli dan berpengetahuan yang cukup tentang perdagangan manusia, praktek korupsi yang memiliki akses ke instansi legal pemerintah serta rendahnya upaya instrumen hukum dalam memberantas masalah perdagangan manusia itu sendiri. Upaya eksternal dilakukan melalui keberadaan Protokol Palermo dan Deklarasi ASEAN, walaupun dalam penerapannya ternyata tidak mudah dikarenakan masih menghadapi beberapa tantangan diantaranya lemahnya komitmen negara terhadap Protokol Palermo dan Deklarasi ASEAN tersebut. Sementara upaya internal dilakukan pemerintah dalam mengawal tenaga kerja perempuan, seperti upaya mengubah pola pikir jenis pekerjaan tenaga kerja perempuan, memperkuat hukum pidana terutama pada tindak pelanggaran terhadap UU PTPPO, sehingga implementasi UU PTPPO dan peraturan turunannya dapat dilaksanakan secara maksimal.

Hasil penelitian ini secara keseluruhan menunjukkan bahwa dalam memberantas persoalan perdagangan manusia selain dengan meningkatkan upaya eksternal dan internal, juga diperlukan peran masyarakat yang sangat signifikan dalam menyelesaikannya dikarenakan peran dari masyarakat merupakan pemicu terjadinya perdagangan manusia sampai dengan menjadi pihak yang melakukan pencegahan dan penanggulangan perdagangan manusia secara langsung.
Sehingga keberhasilan peran pemerintah dalam melakukan pemberantasan perdagangan manusia berhasil atau tidak tergantung dari kemampuan masyarakatnya sebab perdagangan manusia (trafficking) pada dasarnya dipengaruhi oleh adanya pola bias gender yang juga tidak lepas dari dimensi lainnya yang terkait dengan usia, ketidakberdayaan ekonomi, sosial, budaya dan politik yang berkaitan dengan proses industrialisasi serta globalisasi. Pada sisi lain, peran pemerintah melalui aparat penegak hukum dan berbagai pejabat publik yang terkait, membutuhkan koordinasi yang lebih baik, tegas dan bersih dalam penindakan, pencegahan dan perlindungan korban perdagangan manusia.

\section{DAFTAR PUSTAKA}

Abidin, Said Zainal. Kebijakan Publik. Edisi Revisi. Jakarta: Yayasan Pancur Siwak. 2001.

Amiruddin, Mariana. "Wilayah Tertinggal, Migrasi dan Perdagangan Manusia". Jurnal Perempuan, Nomor 59 (2008): 7-20.

ASEAN Declaration Against Trafficking in Persons Particularly Women and Children. 2004, diakses 30 Juli 2017 Pukul 21.30 WITA, http://www.aseanec.org/16793. htm.

Farhana. Aspek Hukum Perdagangan Orang di Indonesia. Jakarta: Sinar Grafika. 2010.

Hidayati, Maslihati Nur. "Upaya Pemberantasan dan Pencegahan Perdagangan Orang Melalui Hukum Internasional dan Hukum Positif Indonesia". Jurnal AL-AZHAR Indonesia Seri Pranata Sosial, Volume 1. Nomor 3 (2012), diakses pada 15 Agustus 2017, Pukul 21:30 WITA, http:// jurnal.uai.ac.id/index.php/SPS/article/ download/59/46. 
IOM (International Organization for Migration). 2001. "Trafficking in Woman and Children From the Republic of America : A Study", diakses pada 15 Agustus 2017, Pukul 21:50 WITA, www.iom.org.

Kempadoo, Kamala. "The War on Human Trafficking in the Caribbean". Race and Class 49 (2007): 79-85.

Mas'oed, Mohtar dan Colin MacAndrews. Perbandingan Sistem Politik. Yogyakarta: Gajah Mada University Press. 1984.

Moeri, Marcella Nirmala Chrisna, Idin Fasisaka, dan Putu Titah Kawitri Resen. "Implementasi Protokol dalam Menanggulangi Permasalahan Tenaga Kerja Wanita Indonesia yang Menjadi Korban Human Trafficking". Jurnal Hubungan Internasional, Volume 1 Nomor 1 (2016), diakses pada 15 Agustus 2017, Pukul 21:00 WITA, https://ojs.unud.ac.id/ index.php/hi/article/view/24370/15809.

Nuraeny, Henny. Tindak Pidana Perdagangan Orang: Kebijakan Hukum Pidana dan Pencegahannya. Jakarta: Sinar Grafika. 2011.

Pettman, Jindy. "Migration", dalam Laura J. Shepherd (ed). Gender Matters in Global Politics: A Feminist Introduction in International Relations. London and New York: Routledge, 2010), 251-264.

Robinson, Fiona. "Sex Trafficking and the Political Economy of Care: A Feminist Moral Analysis", Lokakarya The Political Economy of Care: Transnational Perspectives. Canadian Political Science Association. Vancouver. 4-6 June 2008.

Sagala, R. Valentina. "Membaca UU PTPPO dalam Perspektif HAM". Jurnal Perempuan, Nomor 68 (2010): 85-99.

Subarsono. Analisis Kebijakan Publik (Konsep, Teori dan Aplikasi). Yogyakarta: Pustaka Pelajar. 2009.

Subono, Nur Iman. "Trafficking in Human Beings dalam Angka dan Perdebatan". Jurnal Perempuan, Nomor 68 (2010): 21-36.
Sullivan, Barbara. "Trafficking in Human Being", dalam Laura J. Shepherd (ed). Gender Matters in Global Politics: A Feminist Introduction in International Relations. London and New York: Routledge, 2010), 89-95.

Smith, Emmy Lucy. "Implementasi UU PTPPO bagi Anak Korban Perdagangan”. Jurnal Perempuan, Nomor 68 (2010): 11-19.

Silverman, David. Doing Qualitative Research. London: Sage. 2005.

Undang-undang Nomor 21 Tahun 2007 tentang Pemberantasan Tindak Pidana Perdagangan Orang. Jakarta.

United Nations Protocol to Prevent, Suppress and Punish Trafficking in Persons Especially Women and Children Suplementing the United Nations Convention Against Transnational Organised Crime. 2000.

US Embassy for Indonesia. 2016. "Laporan Tahunan Perdagangan Orang 2016", diakses pada 8 Agustus 2017, Pukul 23:50 WITA, https://id.usembassy.gov/id/ourrelationship-id/official-reports-id.

Wahab, Solichin Abdul. Analisis Kebijakan dari Formulasi ke Implementasi Kebijaksanaan Negara. Jakarta: Bumi Aksara. 2008.

Weitzer, Ronald. "The Social Construction of Sex Trafficking: Ideology and Institutionalization of a Moral Crusade", Politics and Society Nomor 35 (2007): 420 447.

Widodo, Joko. Analisis Kebijakan Publik: Konsep dan Aplikasi Analisis Proses Kebijakan Publik. Malang: Bayu Media. 2010.

Yulia, R. Viktimologi Perlindungan Hukum terhadap Korban Kejahatan. Yogyakarta: Graha Ilmu. 2010.

Zulbahary, Thaufiek. "Menilai Dampak Kebijakan Anti Trafficking di Indonesia terhadap HAM Kelompok Rentan dan Korban". Jurnal Perempuan, Nomor 68 (2010): 37-66. 